\title{
New species and records of Lyssomanes Hentz, 1845 from Central and South Americas (Aranei: Salticidae)
}

\section{Новые виды и находки Lyssomanes Hentz, 1845 из Центральной и Южной Америк (Aranei: Salticidae)}

\author{
D.V. Logunov \\ A.B. Аогунов \\ The Manchester Museum, The University of Manchester, Oxford Road, Manchester M13 9PL, UK. E-mail: \\ dmitri.v.logunov@manchester.ac.uk
}

KEY WORDS: Central America, South America, spiders, Aranei, Salticidae, Lyssomanes, new species, (re)descriptions.

КЛЮЧЕВЫЕ СЛОВА: Центральная Америка, Южная Америка, пауки, Salticidae, Lyssomanes, новые виды, (пере)описания.

ABSTRACT. The paper is devoted to new taxonomic and faunistic data on 36 species of Lyssomanes. Seven new species are diagnosed, figured and described: L. lampeli sp.n. ( ${ }_{+}$, Brazil), L. maddisoni sp.n. ( $\bigcirc^{\top}+$, Mexico), L. manausensis sp.n. ( + , Brazil), L. matoensis sp.n. (†, Brazil), L. mexicanus sp.n. ( $\bigcirc^{7}$, Mexico), L. silvestris sp.n. ( $\odot$, Brazil) and L. similis sp.n. ( + Brazil). Previously unknown females are described for L. anchicaya Galiano, 1984, L. diversus Galiano, 1980 and L. reductus Peckham et Peckham, 1896; these species are also redescribed and figured on the basis of both sexes. Female of L. vinocurae Galiano, 1996 is illustrated and redescribed as well. Six species are figured: L. convexus Banks, 1909 (†), L. lancetillae Galiano, 1980 (+), L. leucomelas Mello-Leitão, 1917 $\left(\bigcirc^{\top}+\right)$, L. malinche Galiano, $1980(+)$, L. miniaceus Peckham et Wheeler, $1889\left(\sigma^{\top}\right)$, and L. tristis Peckham et Wheeler, 1889 ( + ). New faunistic records for 25 Lyssomanes species are provided.

ABSTRACT. Статья посвящена новым таксономическим и фаунистическим данным о 36 видах Lyssomanes. Семь новых видов диагностированы, зарисованы и описаны: L. lampeli sp.n. (†, Бразилия), L. maddisoni sp.n. (○’\%, Мексика), L. manausensis sp.n. (, Бразилия), L. matoensis sp.n. ( зилия), L. mexicanus sp.n. (О', Мексика), L. silvestris sp.n. (†, Бразилия) и L. similis sp.n. (†, Бразилия). Ранее неизвестные самки описаны для L. anchicaya Galiano, 1984, L. diversus Galiano, 1980 и L. reductus Peckham et Peckham, 1896; эти виды также переописаны по обоим полам. Также описана и иллюстрирована самка L. vinocurae Galiano, 1996. Шесть видов проиллюстрированы: L. convexus Banks, 1909 (†), L. lancetillae Galiano, 1980 (†), L. leucomelas Mello-Leitro, 1917 ( $\bigcirc^{\top}+$ ), L. malinche Galiano, 1980 (†), L. miniaceus Peckham et Wheeler, 1889 ( $\left.\bigcirc^{71}\right)$, и L . tristis Peckham et Wheeler, 1889 (†). Новые фаунистические находки даны для 25 видов Lyssomanes.

\section{Introduction}

Lyssomanes Hentz, 1845 is a diverse lyssomanid genus from the Neotropical Region that includes 81 valid species [Galiano, 1962, 1980, 1984, 1996; Brignoli, 1984; Jiménez \& Tejas, 1993; Logunov, 2000a,b, 2002; Logunov \& Marusik, 2003; Logunov \& Deza, 2010; Platnick, 2014], two of which are fossil species from Dominican amber [Wunderlich, 1986, 1988; Dunlop et al., 2013]. The aims of the present paper are (1) to describe seven new Lyssomanes species from Mexico and Brazil, (2) to describe previously unknown females for three other species, and (3) to give new faunistic records with comments for 25 others.

\section{Material and Methods}

A total of 218 newly collected and museum specimens belonging to 36 species of Lyssomanes has been studied. The examined/described material is deposited in the following museums: BMNH - British Museum of Natural History, London, UK (curator: Ms. J. Beccaloni); ONHM - Oxford University Natural History Museum, Oxford, UK (curator: Ms. Z. Simmons); MCZ - Museum of Comparative Zoology, Cambridge, USA (curator: Ms. L. Leibensperger); MHNG - Museum d'Historie Naturelle, Geneve, Switzerland (curator: Dr. P. Schwendinger); MMUM - The Manchester Museum, The University of Manchester, Manchester, UK (curator: Dr. D.V. Logunov); MNBG - Museum für Naturkunde, Berlin, Germany (curator: Dr. J. Dunlop); MNRJ — Museu Nacional, Rio de Janeiro, 
Brazil (curator: Dr. A. Kury); and NNMN - Nationaal Natuurhistorisch Museum Naturalis, Leiden, The Netherlands (curator: Dr. J. Miller).

Abbreviation used in the text: Eyes: AME - anterior median eye, ALE - anterior lateral eye, PME posterior median eye, PLE - posterior lateral eye. Leg segments: Fm - femur, $\mathrm{Pt}$ - patella, Tb - tibia, $\mathrm{Mt}$ metatarsus, $\mathrm{Tr}$ - tarsus. Position of leg spines: $\mathrm{d}-$ dorsal, pr - prolateral, $\mathrm{rt}$ - retrolateral, $\mathrm{v}$ - ventral. For the leg spination the system adopted is that used by Ono [1988]. The sequence of leg segments in measurement data is as follows: femur + patella + tibia + metatarsus + tarsus. All measurements are in mm. Reference lists are given only for the redescribed species, those for other studied species can be found in Platnick [2014].

\section{Descriptions}

\section{Lyssomanes anchicaya Galiano, 1984} Figs 1-6. $\left(\mathrm{D} \sigma^{7}\right)$

Lyssomanes anchicaya Galiano, 1984: 268, fig. 1, 2, 12-16

MATERIAL. COLOMBIA: $10^{7}$ (MCZ, 77504), Nariño, La Planada, c. $7 \mathrm{~km} \mathrm{~S}$ of Chocones, [Andes Mt. Range], $1800 \mathrm{~m}$ a.s.l., 07.1986, W.G. Eberhard; 1 + (MCZ, 77467), Valle, ca. Pichinde, [Andes Mt. Range], 1700 m a.s.l., 17.09.1975, W.G. Eberhard. COSTA RICA: $1 \mathrm{O}^{7}$ (MCZ, 77501), Puntarenas, Osa Peninsula, c. 2.5 miles SW of Rincon $\left(8^{\circ} 42^{\prime} \mathrm{N}, 83^{\circ} 29^{\prime} \mathrm{W}\right), 31 / 01 / 1967$, coll? $1 \mathrm{O}^{\top}$ (MCZ, 77471), Heredia, nr. Puerto Viejo, La Selva, 22.01.1979, J. Coddington; $1 O^{7}$ (MCZ, 77488), same locality, c. $100 \mathrm{~m}$ a.s.l., 03.1983, W.G. Eberhard; 1 O $^{7}$ (MCZ, 77508), San José, Bajo Hondura, c. $1300 \mathrm{~m}$ a.s.1., 03.1985, W.G. Eberhard. - PANAMA: 1 o (MCZ, 77528), nr. Gamboa, Pipeline Road, c. 20 m a.s.l., 05.1986 W.G. Eberhard; $1 \sigma^{7}$ (NNMN), Somberia, nr N.P. Canal zone, f. leaves, 7.08.1983, C.L. \& P.R. Deeleman.

DIAGNOSIS. By the palp conformation, the male is most similar to those of L. nigrofimbriatus MelloLeitão, 1940 and L. robustus (Taczanowski, 1878) [cf. Galiano, 1962: pl. II, figs 5-7; 1980: figs 38-40], but differs from both in having the longer, whip-shaped embolus with a well-marked basal tooth (Fig. 1). The female of L. anchicaya is unique among all the Lyssomanes species known to me in having the widely spaced bean-shaped receptacles and straight tube-shaped insemination ducts (Fig. 6). See also comments below under 'Diagnosis' of L. mexicanus sp.n. The female of L. anchicaya is found and described for the first time.

COMMENTS. The males and the female are matched provisionally on account of the fact that the studied samples with opposite sexes were collected from the Andes Mt. Range in Colombia from the close localities lying at the same altitude. This is the first record of the species after its original description.

DISTRIBUTION. Central America. To date, this species has been known from the male holotype from central Colombia only [Galiano, 1984]. New records for Costa Rica and Panama.

DESCRIPTION. Male (MCZ, 77504). Measurements. Carapace 2.40 long, 1.75 wide, 1.38 high at PLE. Ocular area 1.20 long; width of eye rows: AMEAME-row 1.25, ALE-ALE-row 1.20, PLE-PLE-row
0.73. Diameter of AME 0.60. Abdomen 3.65 long, 1.10 wide. Cheliceral length 2.20. Clypeal height 0.13 . Length of leg segments: I $3.30+1.05+3.05+2.75+$ $0.70 ;$ II $3.00+1.00+2.55+2.40+0.60$; III $2.75+$ $0.70+2.15+2.65+0.75 ;$ IV $2.75+0.70+2.55+3.15$ +0.70 . Leg spination: I: Fm d 1-1-1-1, pr and rt 0-1-1; Tb pr and rt 0-0-1, v 4 pairs; Mt v 3 pairs. II: Fm d 1-11, pr and rt 0-1-1; Tb pr and rt 0-0-1, v 4 pairs; Mt v 3 pairs. III: Fm d 1-1-1, pr and rt 0-1-1; Pt d 1ap; Tb d 1$0-0$, pr and rt 1-1, v 0-0-1; Mt v 1-2. IV: Fm d 1-1-2; Pt d 1ap; Tb d 1-0-0, rt 0-0-1. Coloration (in alcohol). Entire body, legs and palps yellow, but blackened around ALEs, PMEs and PLEs, and with brownish rings in Tb/Mt joints and Tr I brownish. Dorsum with two pairs of brownish spots (Fig. 4). Palpal structure as in Figs 1-3: median apophysis wide, with an apical tooth; conductor mushroom-shaped; embolus thin and relatively long; and cymbium with medium-sized tutaculum.

Female (MCZ, 77467). Measurements. Carapace 2.75 long, 2.03 wide, 1.30 high at PLE. Ocular area 1.28 long; width of eye rows: AME-AME-row 1.23, ALE-ALE-row 1.38, PLE-PLE-row 1.05. Diameter of AME 0.63. Abdomen 4.40 long, 2.10 wide. Cheliceral length 1.50. Clypeal height 0.13. Length of leg segments: I $3.30+1.30+3.20+3.00+0.65$; II $2.85+$ $1.05+2.55+2.40+0.60 ;$ III $22.85+0.85+2.40+$ $2.60+0.65 ;$ IV $2.85+0.75+2.45+2.90+0.60$. Leg spination: I and II: Fm d 1-1-1, pr and rt 0-1-1; Tb pr and rt $0-0-1$, v 4 pairs; Mt v 3 pairs. III: Fm d 1-1-1, pr and rt $0-1-1$; Pt d 1ap; Tb d 1-0-0, pr and v 0-1, rt 1-1; Mt v 2 pairs. IV: Fm d 1-1-2; Pt d 1ap; Tb d 1-0-0. Coloration (in alcohol). Entire body, all legs and palps yellow, but chelicerae and palpal tarsi darker (tinged with brownish) and Tr I brownish. Abdomen with no colour pattern. Blackened around ALEs, PMEs and PLEs. Epigyne and vulva as in Figs 5-6: copulation openings are markedly spaced; epigynal pocket absent; tube-like and straight insemination ducts, with welldeveloped, long fertilization ducts, bean-shaped receptacles.

\section{Lyssomanes diversus Galiano, 1980}

Figs $7-14$

Lyssomanes diversus Galiano, 1980: 66, fig. 145-148 (D $\left.\sigma^{7}\right)$.

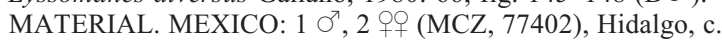
$20 \mathrm{~km}$ NE of Tlanchinol on HWY 105 (c. $21^{\circ} 07^{\prime} \mathrm{N}, 98^{\circ} 34^{\prime} \mathrm{W}$ ), c. $2500 \mathrm{ft}$ a.s.1., 14.06.1983, W. Maddison \& M. Kaulbars; $1 \sigma^{7}, 1$ 우 (MCZ, 77396), Nuevo León, Santa Rosa canyon, c. $29 \mathrm{~km} \mathrm{~W} \mathrm{of}$ Linares along HWY 60 (c. $21.8^{\circ} \mathrm{N}, 99.8^{\circ} \mathrm{W}$ ), c. $2000 \mathrm{ft}$ a.s.1., 34.06.1983, W. Maddison.

DIAGNOSIS. This species is most similar to $L$. burrera Jiménez et Tejas, 1993 from Mexico [see Jiménez \& Tejas, 1993: figs 4-8] and L. jemineus Peckham, Peckham et Wheeler, 1889 known from many Neotropical countries [see Galiano, 1980: figs 133137, 149-152], but can be easily distinguished from both by the presence of long basal tooth of the embolus (embolus bifurcated; Fig. 7) and the shape of median apophysis (Fig. 9) in the males and by the larger, ovoid 

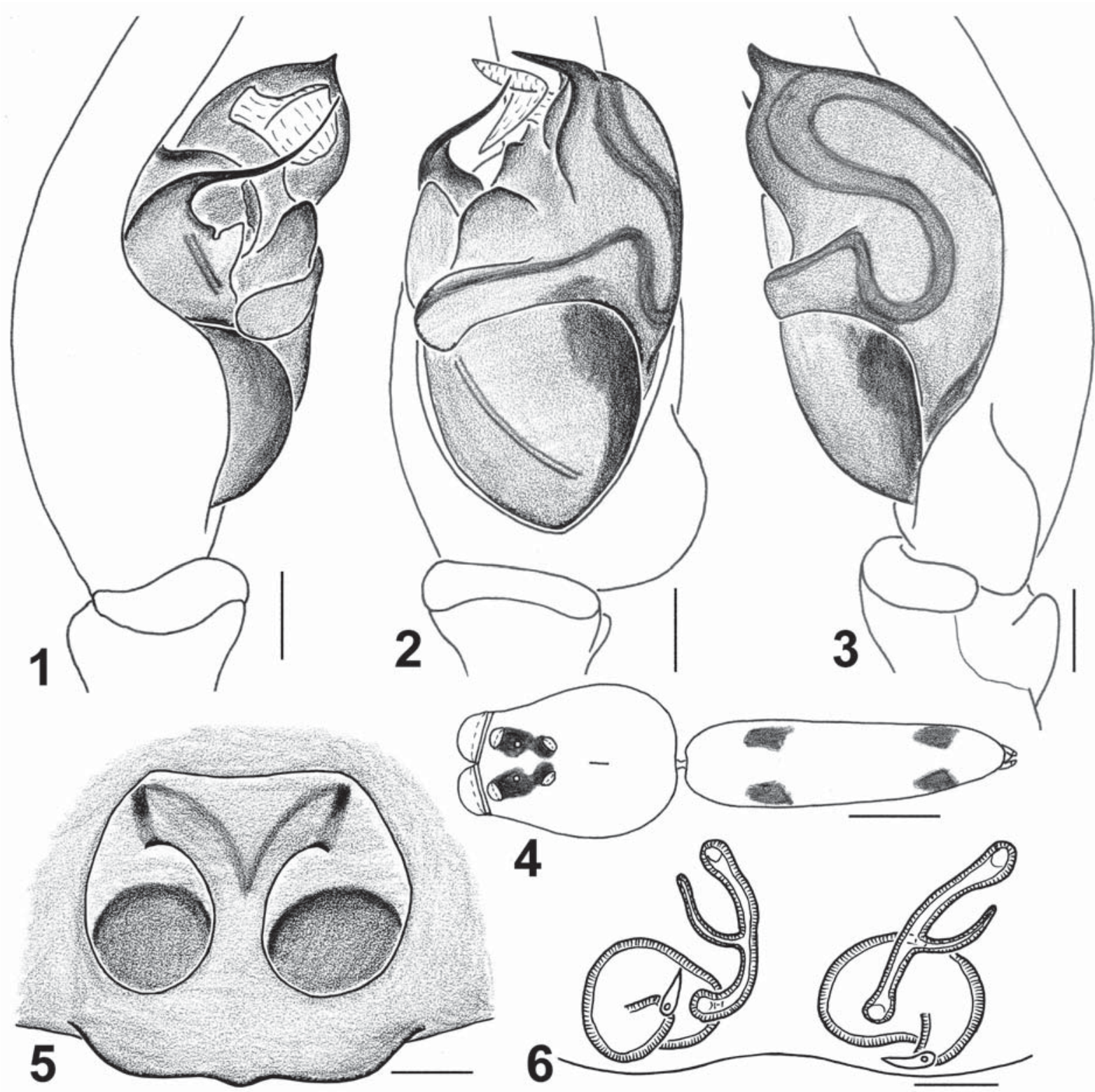

Figs 1-6. Copulatory organs and general appearance of Lyssomanes anchicaya Galiano, 1984 ( $0^{7}$ from Chocones, Colombia; 9 from Pichinde, Colombia): 1 - male palp, prolateral view; 2 - ditto, ventral view; 3 - ditto, retrolateral view; 4 - male general appearance, dorsal view; 5 - epigyne, ventral view; 6 - vulva, dorsal view. Scale bars: $0.1 \mathrm{~mm}(1-3,5-6), 1 \mathrm{~mm}$ (4).

Рис. 1-6. Копулятивные органы и общий вид Lyssomanes anchicaya Galiano, 1984 ( ${ }^{\text {T }}$ из Чоконес, Колумбия; 9 из Пичинде, Колумбия): 1 - пальпа самца, вид пролатерально; 2 - тоже, вид снизу; 3 - тоже, вид ретролатерально; 4 - общий вид самца, вид сверху; 5 - эпигина, вид снизу; 6 - вульва, вид сверху. Масштаб: 0,1 мм (1-3, 5-6), 1 мм (4).

receptacles and shorter insemination ducts (Fig. 14) in the females. Besides, the male's dorsum of L. diversus has a wide dark grey longitudinal band (Fig. 12), whereas those of related species two longitudinal dark brown stripes. The female of $L$. diversus is found and described for the first time.

DISTRIBUTION. Mexico: Nuevo León and Hidalgo [Galiano, 1980; present data].

DESCRIPTION. Male (MCZ, 77402). Measurements. Carapace 2.75 long, 2.23 wide, 1.90 high at
PLE. Ocular area 1.43 long; width of eye rows: AMEAME-row 1.20, ALE-ALE-row 1.10, PLE-PLE-row 0.85. Diameter of AME 0.60. Abdomen 4.20 long, 1.25 wide. Cheliceral length 2.25. Clypeal height 0.23 . Length of leg segments: I $3.85+1.25+3.90+4.00+$ $0.65 ;$ II $3.20+1.05+2.85+2.95+0.60 ;$ III $3.00+$ $0.90+4.50+3.00+0.60 ;$ IV $2.90+0.75+2.60+3.30$ +0.55 . Leg spination: I: Fm d 1-1-1, pr and rt 0-1-1; Tb pr and rt $0-0-1, \mathrm{v} 4$ pairs; Mt pr $1-0-0$, v 3 pairs and dorsal and ventral rows of dense dark brown hairs (Fig. 


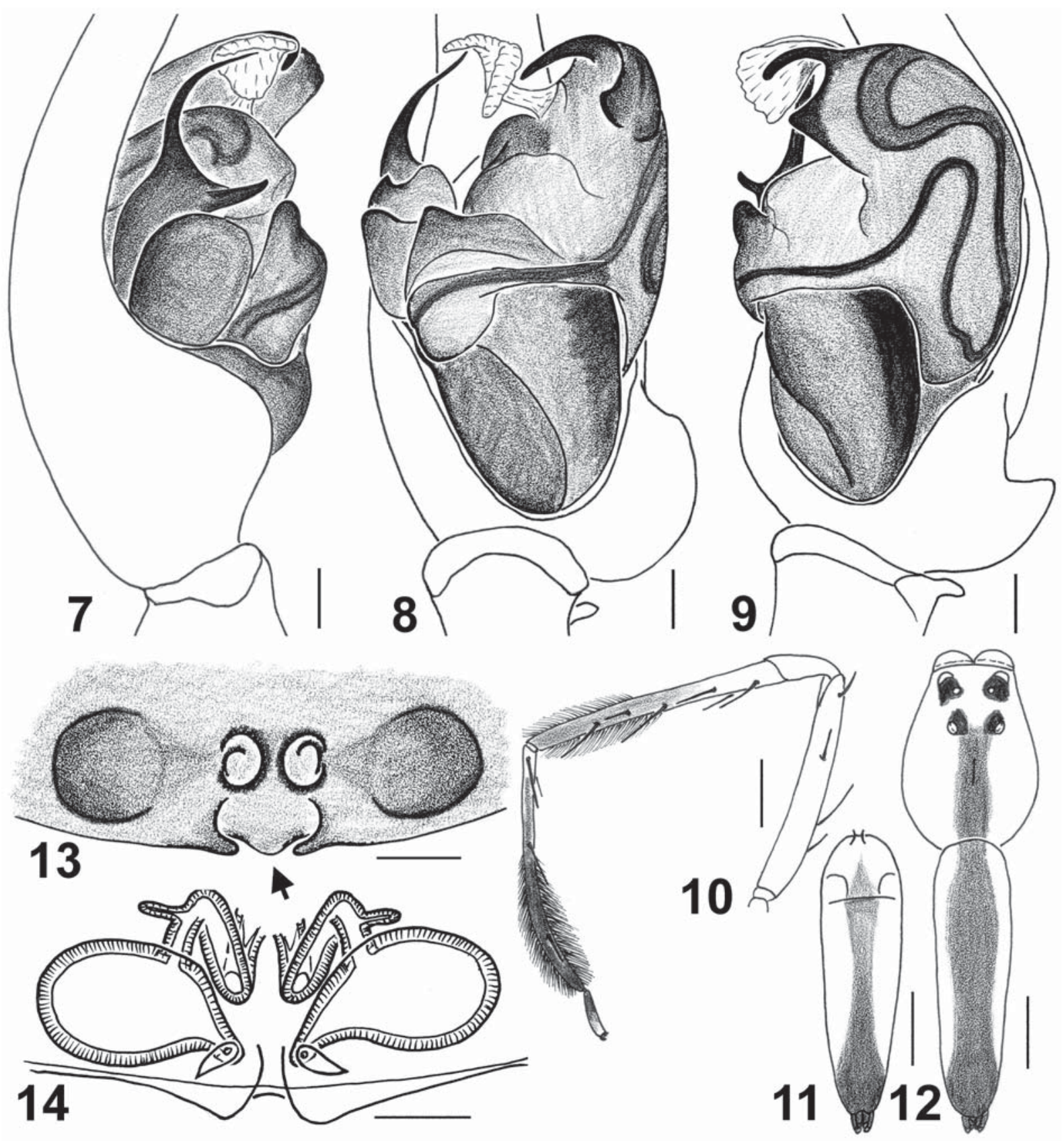

Figs 7-14. Copulatory organs and general appearance of Lyssomanes diversus Galiano, 1980 from Hidalgo, Mexico: 7 - male palp, prolateral view; 8 - ditto, ventral view; 9 - ditto, retrolateral view; 10 - male leg I, lateral view; 11 - male abdomen, ventral view; 12 - male general appearance, dorsal view; 13 - epigyne, ventral view; 14 - vulva, dorsal view. Scale bars: $0.1 \mathrm{~mm}(7-9,13-14), 1 \mathrm{~mm}$ $(10-12)$.

Рис. 7-14. Копулятивные органы и общий вид Lyssomanes diversus Galiano, 1980 из Идальго, Мексика: 7 — пальпа самца, вид пролатерально; 8 - тоже, вид снизу; 9 - тоже, вид ретролатерально; 10 - нога І самца, вид сбоку; 11 - брюшко самца, вид снизу; 12 - общий вид самца, вид сверху; 13 - эпигина, вид снизу; 14 - вульва, вид сверху. Масштаб: 0,1 мм (7-9, 13-14), 1 мм $(10-12)$.

10). II: Fm d 1-1-1, pr and rt 0-1-1; Pt d 1ap; Tb pr and rt 1-1, v 3 pairs; Mt pr 1-0-0, v 3 pairs. III: Fm d 1-1-1, pr and rt 0-1-1; Pt d 1ap; Tb d 0-1, pr and rt 1-1, v 2-0; Mt pr 1-0-0, v 3 pairs. IV: Fm d 1-1-1, pr and rt 0-0-1; Pt d lap; Tb d, pr and rt 1-1, Mt d and pr 0-1-0, rt 1-1. Coloration (in alcohol). Carapace yellow, but black- ened around ALEs, PMEs and PLEs, and with a longitudinal median dark grey strip behind PLEs (Fig. 12). Maxillae and labium yellow. Chelicerae long, light brown. Abdomen yellow, with wide dorsal dark grey median stripe as shown in Fig. 12; venter yellow, with wide median dark grey stripe (Fig. 11). Book-lung 
covers yellow. Spinnerets dark grey. Legs I yellow, but Tb brownish in its distal half, Mt brown and Tr brownish in its basal half; besides, Tb I and Mt I bear dense rows of dorsal and ventral hairs (Fig. 10). Legs II yellow, but $\mathrm{Tb}$ distally brownish. Legs III-IV completely yellow. Palps: $\mathrm{Tb}$ and $\mathrm{Pt}$ yellow, remaining segments brownish. Palpal structure as in Figs 7-9: median apophysis wide, with apical hook and proximal angle; conductor mushroom-shaped; embolus bifurcated; and cymbium with large, angled tutaculum.

Female (MCZ, 77402). Measurements. Carapace 2.55 long, 2.15 wide, 1.45 high at PLE. Ocular area 1.45 long; width of eye rows: AME-AME-row 1.15, ALE-ALE-row 1.08, PLE-PLE-row 0.83. Diameter of AME 0.60. Abdomen 3.90 long, 1.50 wide. Cheliceral length 1.38. Clypeal height 0.20. Length of leg segments: I $3.05+1.25+2.85+2.80+0.58$; II $2.75+$ $1.00+2.30+2.25+0.58 ;$ III $2.65+0.95+2.08+2.40$ +0.60 ; IV $2.50+0.75+2.15+2.70+0.60$. Leg spination: I: Fm d 1-1-1, pr and rt 0-1-1; Tb pr 0-1-1, rt $0-0-1$, v 4 pairs; Mt pr 1-0, v 3 pairs. II: Fm d 1-1-1, pr and rt 0-1-1; Pt d 1ap; Tb d, pr and rt 1-1, v 3 pairs; Mt pr and rt 1-0-0, v 3 pairs. III: Fm d 1-1-1, pr and rt 0-11; Pt d 1ap; Tb d 0-1, pr and rt 1-1, v 2-2; Mt pr and rt 1-1, v 2-1ap. IV: Fm d 1-1-1, pr and rt 0-0-1; Pt d 1ap; Tb d, pr and rt 1-1, v 1-0, Mt pr 1-1-1ap, rt 1-0-0, v 10-0. Coloration (in alcohol). Entire body, all legs and palps yellow. Abdomen with no colour pattern. Blackened around ALEs, PMEs and PLEs, plus eye field with orange scales. Epigyne and vulva as in Figs 1314: two round copulation openings situated close to each other in the centre of the epigynal plate; paired epigynal pocket present (arrowed in Fig. 13); tube-like insemination ducts and ovoid receptacles.

\section{Lyssomanes lampeli sp.n.}

Figs 19-20.

TYPE MATERIAL. Holotype + (ONHM) from Guyana, "British Guiana: Lyss. green \& tramp ... sepwall heardbeat ... on long leaf Kaucuuk Tr, Amatuk, 3/8/59/5, B.G.”, G.P. Lampel [handwritten label is illegible; apparently from Georgetown, Guyana].

ETYMOLOGY. The species is named after the famous collecor G.P. Lampel, who collected the holotype and whose collections are deposited at the ONHM.

DIAGNOSIS. This species seems to belong to the robustus species group [sensu Galiano, 1980]. It can be easily distinguished from all the Lyssomanes species known to me by the unique conformation of the copulatory organs (Figs 19-20), viz., the C-shaped insemination ducts that first run laterad and then turn mediad meeting along the median line and by the large, pear-shaped receptacles.

DISTRIBUTION. The type locality only: Guyana.

DESCRIPTION. Male unknown.

Female. Measurements. Carapace 2.95 long, 2.00 wide, 1.50 high at PLE. Ocular area 1.55 long; width of eye rows: AME-AME-row 1.40, ALE-ALE-row 1.40, PLE-PLE-row 1.03. Diameter of AME 0.68. Abdomen 3.25 long, 1.20 wide. Cheliceral length 1.13. Clypeal height 0.20 . Length of leg segments: I $3.35+1.15+$ $3.25+3.15+0.78$; II $3.00+1.05+2.83+2.90+0.75$; III $2.90+0.80+2.40+3.20+0.70$; IV $2.95+0.80+$ $2.60+3.55+0.75$. Leg spination: I and II: Fm d 1-1-1, pr and rt 0-1-1; Pt d 1ap; Tb d, pr and rt 0-1, v 4 pairs; Mt pr and rt 1-0-0, v 3 pairs. III: Fm d 1-1-1, pr and rt 0-1-1; Pt d 1ap; Tb pr 1-1, rt 0-1, v 2-2; Mt pr 1-0-0, rt 1-1-0, v 3 pairs. IV: Fm d 1-1-3; Pt d 1ap; Tb pr and rt $1-1$, pr and $\mathrm{v} 0-1$; Mt d 0-1-0, pr and rt 1-1-0, v 2 pairs. Coloration (in alcohol). Entire body, all legs and palps yellow. Abdomen with no colour pattern. Blackened around ALEs, PMEs and PLEs. Epigyne and vulva as in Figs 19-20: copulation openings are widely separated; epigynal pocket absent; $\mathrm{C}$-shaped tube-like insemination ducts; large, pear-shaped receptacles.

\section{Lyssomanes maddisoni sp.n.}

Figs 22-29.

TYPE MATERIAL. Holotype $\sigma^{7}$ (MCZ, 77392) from Mexico, Veracruz, Estacion de Biologia Tropical 'Los Tuxtlas' (UNAM), nr. La Palma, N of Catemaco (c. $18^{\circ} 36^{\prime} \mathrm{N}, 95^{\circ} 07^{\prime} \mathrm{W}$ ), short tropical rainforest, 1-2.08.1983, W. Maddison.

Paratypes: 19 (MCZ, 77392), together with the holotype; $10^{7}$, 1 o (MCZ, 77400), same locality, 29.06-1.07.1983, W. Maddison.

ETYMOLOGY. The species is named after Prof Wayne Maddison, the well-known arachnologist who collected the type series.

DIAGNOSIS. The male of L. maddisoni sp.n. can easily be distinguished from all the Lyssomanes species known to me by the presence of the unique, strongly serrated median apophysis (Fig. 24). Besides, the male palpal tibia bears a bunch of strong and long bristles (Fig. 27), a rare feature in Lyssomanes. By the presence of central transverse atrium of the epigyne (Fig. 28), the female of L. maddisoni sp.n. is most similar to those of L. pescadero Jiménez et Tejas, 1993 from Mexico [Jiménez \& Tejas, 1993: figs 14-15] and L. lancetillae Galiano, 1980 from Honduras and Nicaragua (Figs 63-64; see also Galiano [1980: figs. 50$51]$ ), but can be distinguished by the ovoid receptacles (Fig. 29).

DISTRIBUTION. The type locality only: Mexico, Veracruz.

DESCRIPTION. Male (the holotype). Measurements. Carapace 2.60 long, 1.85 wide, 1.55 high at PLE. Ocular area 1.35 long; width of eye rows: AMEAME-row 1.23, ALE-ALE-row 1.28, PLE-PLE-row 0.88. Diameter of AME 0.60. Abdomen 3.90 long, 1.10 wide. Cheliceral length 1.10. Clypeal height 0.20 . Length of leg segments: I $3.85+1.20+4.05+4.20+$ $0.70 ;$ II $3.20+1.00+2.75+3.00+0.60 ;$ III $3.00+$ $0.90+2.50+3.05+0.60 ;$ IV $2.90+0.80+2.60+3.50$ +0.60 . Leg spination: I: Fm d, pr and rt 0-1-1; Tb pr 01-1, rt 1-1-1, v 3 pairs; Mt pr and rt 1-0-0, v 3 pairs and dorsal and ventral rows of dense dark brown hairs (Fig. 25). II: Fm d 1-1-1, pr and rt 0-1-1; Pt d 1ap; Tb d 0-1, pr and rt 1-1, v 3 pairs; Mt pr and rt 1-0, v 3 pairs. III: Fm d 1-1-1, pr and rt 0-1-1; Pt d 1ap; Tb d 0-1, pr and rt 1-1, v 0-2; Mt pr and rt 1-1-0, v 2-0-0. IV: Fm d 1-11, pr and rt 0-0-1; Pt d 1ap; Tb pr and rt 1-1, v 3 pairs, 

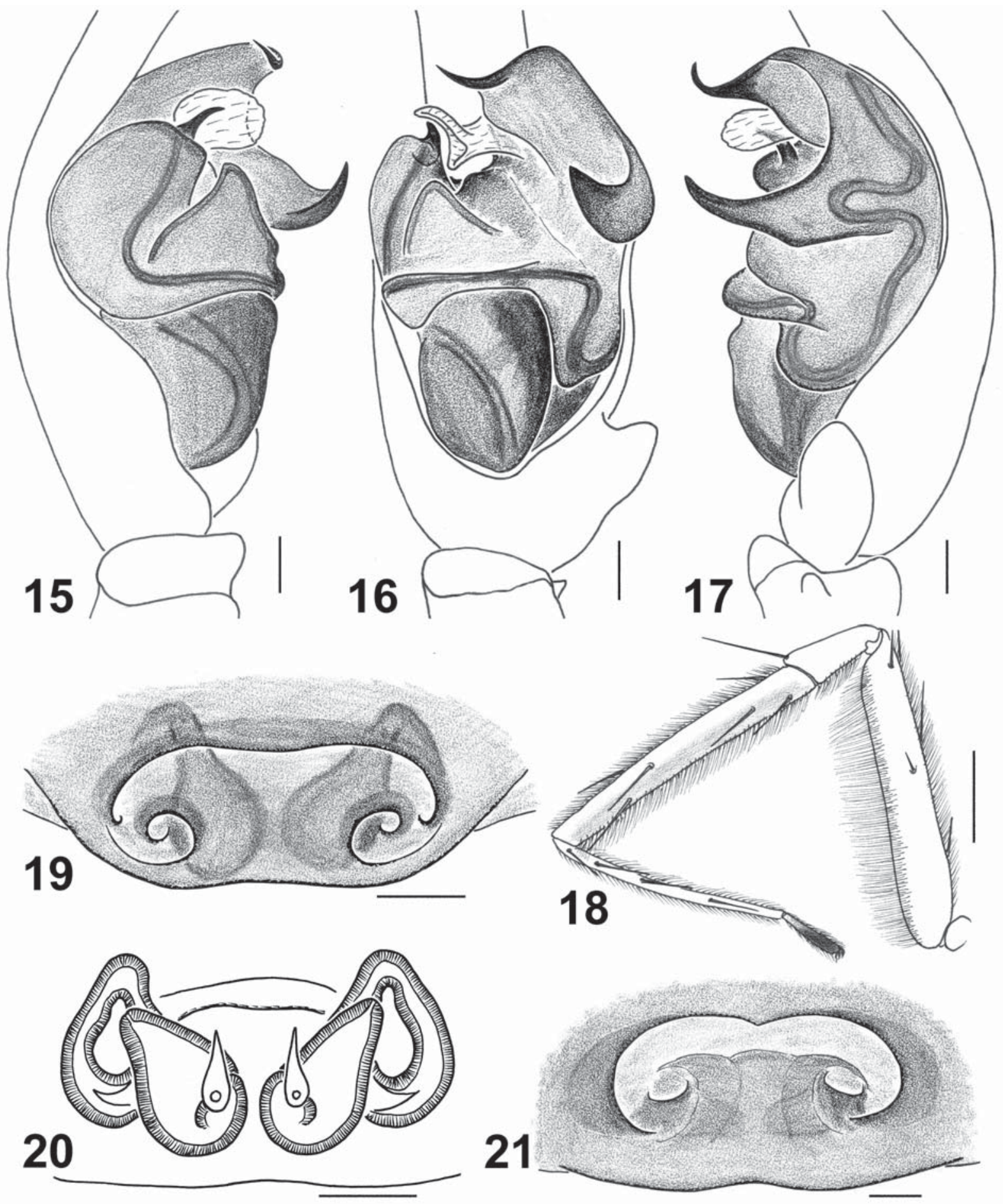

Figs 15-21. Copulatory organs and leg of Lyssomanes miniaceus Peckham, Peckham et Wheeler, 1889 (15-18, from Rio Grande River, Brazil), L. lampeli sp.n. (19-20, the holotype) and L. tristis Peckham, Peckham et Wheeler, 1889 (21, from Rio Grande River, Brazil): 15 - male palp, prolateral view; 16 - ditto, ventral view; 17 - ditto, retrolateral view; 18 - male leg I, lateral view; 19, 21 epigyne, ventral view; 20 - vulva, dorsal view. Scale bars: $0.1 \mathrm{~mm}(15-17,19-21), 1 \mathrm{~mm}(18)$.

Рис. 15-21. Копулятивные органы и нога Lyssomanes miniaceus Peckham, Peckham et Wheeler, 1889 (15-18, с реки Рио Гранде, Бразилия), L. lampeli sp.n. (19-20, голотип) и L. tristis Peckham, Peckham et Wheeler, 1889 (21, с реки Рио Гранде, Бразилия): $15-$ пальпа самца, вид пролатерально; 16 - тоже, вид снизу; 17 - тоже, вид ретролатерально; 18 - нога I самца, вид сбоку; 19, 21 эпигина, вид снизу; 20 - вульва, вид сверху. Масштаб: 0,1 мм (15-17, 19-21), 1 мм (18). 

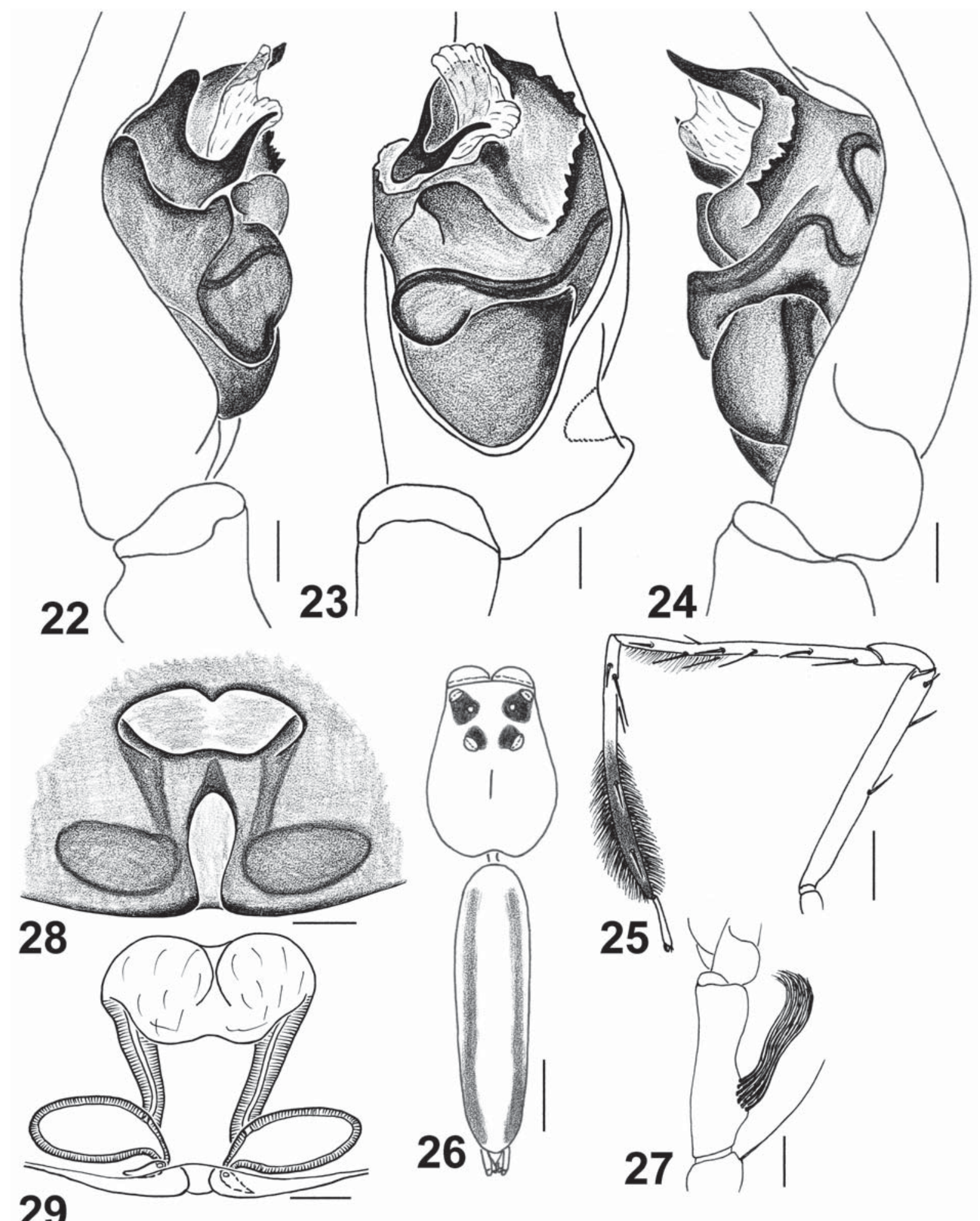

Figs 22-29. Copulatory organs and somatic characters of Lyssomanes maddisoni sp.n. ( $0^{7}$, the holotype, 9 from Veracruz, Mexico): $22-$ male palp, prolateral view; 23 - ditto, ventral view; 24 - ditto, retrolateral view; 25 - male leg I, lateral view; 26 - male general appearance, dorsal view; 26 - Tb of male palp, ventral view; 28 - epigyne, ventral view; 29 - vulva, dorsal view. Scale bars: $0.1 \mathrm{~mm}$ (22-24, 28-29), $0.25 \mathrm{~mm}(27), 1 \mathrm{~mm}(25-26)$.

Рис. 22-29. Копулятивные органы и соматические признаки Lyssomanes maddisoni sp.n. ( $\bigcirc^{7}$ голотип, + из Веракрус, Мексика): 22 - пальпа самца, вид пролатерально; 23 - тоже, вид снизу; 24 - тоже, вид ретролатерально; 25 - нога I самца, вид сбоку; 26 - внешний вид самца, вид сверху; 27 - голень пальпы самца, вид снизу; 28 - эпигина, вид снизу; 29 - вульва, вид сверху. Масштаб: 0,1 мм (22-24, 28-29), 0,25 мм (27), 1 мм (25-26). 
Mt pr and rt 1-0-0, v 3 pairs. Coloration (in alcohol). Entire body, legs and palps yellow. Carapace blackened around ALEs, PMEs and PLEs, and dorsum with two longitudinal dark grey stripes (Fig. 26). Legs I with $\mathrm{Tb}$ being brownish in their distal halves and also bearing dense rows of dorsal and ventral hairs (Fig. 25). Palpal structure as in Figs 22-24: tibia with a bunch of strong, long bristles; cymbium with large tutaculum; median apophysis wide, with serrated prolateral edge; conductor leaf-shaped; embolus bifurcated.

Female (the illustrated ${ }^{\circ}$; MCZ, 77392). Measurements. Carapace 2.60 long, 1.90 wide, 1.25 high at PLE. Ocular area 1.35 long; width of eye rows: AMEAME-row 1.18, ALE-ALE-row 1.23, PLE-PLE-row 0.88. Diameter of AME 0.60. Abdomen 3.70 long, 1.40 wide. Cheliceral length 1.10 . Clypeal height 0.18 . Length of leg segments: I $2.75+1.05+2.50+2.40+$ $0.60 ;$ II $2.35+0.93+1.95+2.00+0.60 ;$ III $2.20+$ $0.80+1.75+2.10+0.55 ;$ IV $2.25+0.65+1.90+2.40$ +0.55 . Leg spination: I: Fm d 1-1-1, pr and rt 0-1-1; Tb pr and rt 1-1, v 3 pairs; Mt pr and rt 1-0-0, v 3 pairs. II: Fm d 1-1-1, pr and rt 0-1-1; Tb pr and rt 1-1, v 3 pairs; Mt pr and rt 1-0-0, v 3 pairs. III: Fm d 1-1-1, pr and rt 0-1-1; Pt d 1ap; Tb d, pr and rt 1-1, v 0-2; Mt pr and rt 1-0, v 2-2ap. IV: Fm d 1-1-1, pr 0-1-0, rt 1ap; Pt $\mathrm{d} 1 \mathrm{ap}$; Tb pr and rt 1-1, Mt pr and v 0-1-0. Coloration (in alcohol). Entire body, all legs and palps yellow. Carapace blackened around ALEs, PMEs and PLEs, eye field with orange scales. Abdomen with no colour pattern. Epigyne and vulva as in Figs 28-29: copulation openings are situated inside central transverse atrium; long epigynal pocket present; relatively short, tubelike insemination ducts and ovoid receptacles.

\section{Lyssomanes manausensis sp.n.} Figs 34-36.

TYPE MATERIAL. Holotype + (MCZ, 77423) from Brazil, Amazonas, c. $80 \mathrm{~km} \mathrm{~N}$ of Manaus, Colosso Reserve, border of forest and its interior, 5.12.1989, H.G. Fowler.

ETYMOLOGY. The species epithet is derived from the name of city of Manaus in Brazil.

DIAGNOSIS. By the conformation of the epigyne (viz., the small copulation openings situated in the centre of the epigynal plate; Fig. 35), this species is most similar to L. longipes (Taczanowski, 1871) from Brazil, Guyana and French Guiana [cf. Galiano, 1980: figs 6-7] and to L. euriensis Logunov, 2000 from Peru [cf. Logunov, 2000a: figs 3-5]. From both it can be distinguished by the much shorter insemination ducts and the retort-shaped receptacles (Fig. 34). Besides, the colour pattern of carapace of $L$. manausensis sp.n. (Fig. 36) is different from that of L. euriensis.

DISTRIBUTION. The type locality only: Brazil, Colosso Reserve.

DESCRIPTION. Male unknown.

Female. Measurements. Carapace 2.00 long, 1.28 wide, 0.83 high at PLE. Ocular area 1.10 long; width of eye rows: AME-AME-row 0.95, ALE-ALE-row 1.10, PLE-PLE-row 0.75. Diameter of AME 0.48. Abdomen
3.00 long, 2.08 wide. Cheliceral length 0.70. Clypeal height 0.08 . Length of leg segments: I $2.45+0.90+$ $2.30+2.40+0.65 ;$ II $1.95+0.55+1.63+1.75+0.55$; III $1.85+0.48+1.60+2.05+0.60$; IV $2.05+0.48+$ $1.90+2.45+0.65$. Leg spination: I and II: Fm d 0-1-2, v 0-2-2-0; Tb v 5 pairs; Mt v 5 pairs. III and IV: Fm d 1-1-1; Pt d 1ap; Tb d 1ap. Coloration (in alcohol). Carapace brownish yellow, with narrows marginal brownish line and wide brownish median band at thorax (Fig. 36), blackened around ALEs, PMEs and PLEs, and eye field with white scales. Sternum, labium, maxillae and chelicerae pale yellow. Abdomen pale yellow, with a grey pattern consisting of wide stripes and patches on dorsum (Fig. 36). Leg I: pale yellow, with brownish stripes on pro- and retrolateral sides of femur. Legs II-IV entirely pale yellow. Palps pale yellow. Epigyne and vulva as in Figs 34-35: copulation openings situated in the centre of the epigynal plate, close to each other; epigynal pocket welldeveloped; relatively short, tube-like insemination ducts and retort-shaped receptacles.

\section{Lyssomanes matoensis sp.n.}

Figs 30-31.

TYPE MATERIAL. Holotype $q$ (MCZ, 77474) from Brazil, Mato Grosso, c. $260 \mathrm{~km} \mathrm{~N}$ of Xavantina $\left(12^{\circ} 49^{\prime} \mathrm{S}, 51^{\circ} 46^{\prime} \mathrm{W}\right)$, 30.11.1968, expedition Xavantina-Cachimbo.

ETYMOLOGY. The species epithet is originated from the name of type locality: Mato Grosso in Brazil.

DIAGNOSIS. The female of L. matoensis sp.n. (Figs 30-31) is most similar to those of L. eatoni Chickering, 1946 from Panama, L. convexus Banks, 1909 from Costa Rica and L. portoricensis Petrunkevitch, 1930 from Puerto Rico, of which two remain known from the females only. All these species have the widely spaced copulatory openings and the thin insemination ducts running towards the median line of the epigyne [see Galiano, 1980: figs 25-26, 121-122, 125-126; Logunov \& Marusik, 2003: figs 13-14; also Figs 32-33]. From all these species L. matoensis sp.n. differs in having the larger, transversely-ovoid receptacles (Fig. 31).

DISTRIBUTION. The type locality only: Brazil, Mato Grosso.

DESCRIPTION. Male unknown.

Female. Measurements. Carapace 3.15 long, 2.28 wide, 1.80 high at PLE. Ocular area 1.35 long; width of eye rows: AME-AME-row 1.35, ALE-ALE-row 1.48, PLE-PLE-row 1.05. Diameter of AME 0.65. Abdomen 5.50 long, 2.15 wide. Cheliceral length 1.75. Clypeal height 0.23 . Length of leg segments: I $3.80+1.45+$ $3.50+3.35+0.70 ;$ II $3.25+1.10+2.80+2.80+0.68$; III $3.15+1.05+2.50+2.95+0.65$; IV $2.95+0.90+$ $2.70+3.50+0.65$. Leg spination: I and II: Fm d 1-1-1, pr and rt 0-1-1; Tb rt 0-1, v 4 pairs; Mt pr and rt 1-0-0, v 3 pairs. III: Fm d 1-1-1, pr and rt 0-1-1; Pt d 1ap; Tb pr and rt 1-1, v 0-2; Mt pr and rt 1-0-0, v 2-2-0. IV: Fm d 0-1-2; Pt d 1ap; Tb pr and rt 1-1, v 0-1; Mt rt 1-0-0, v 1-1-2. Coloration (in alcohol). Entire body, all legs and 


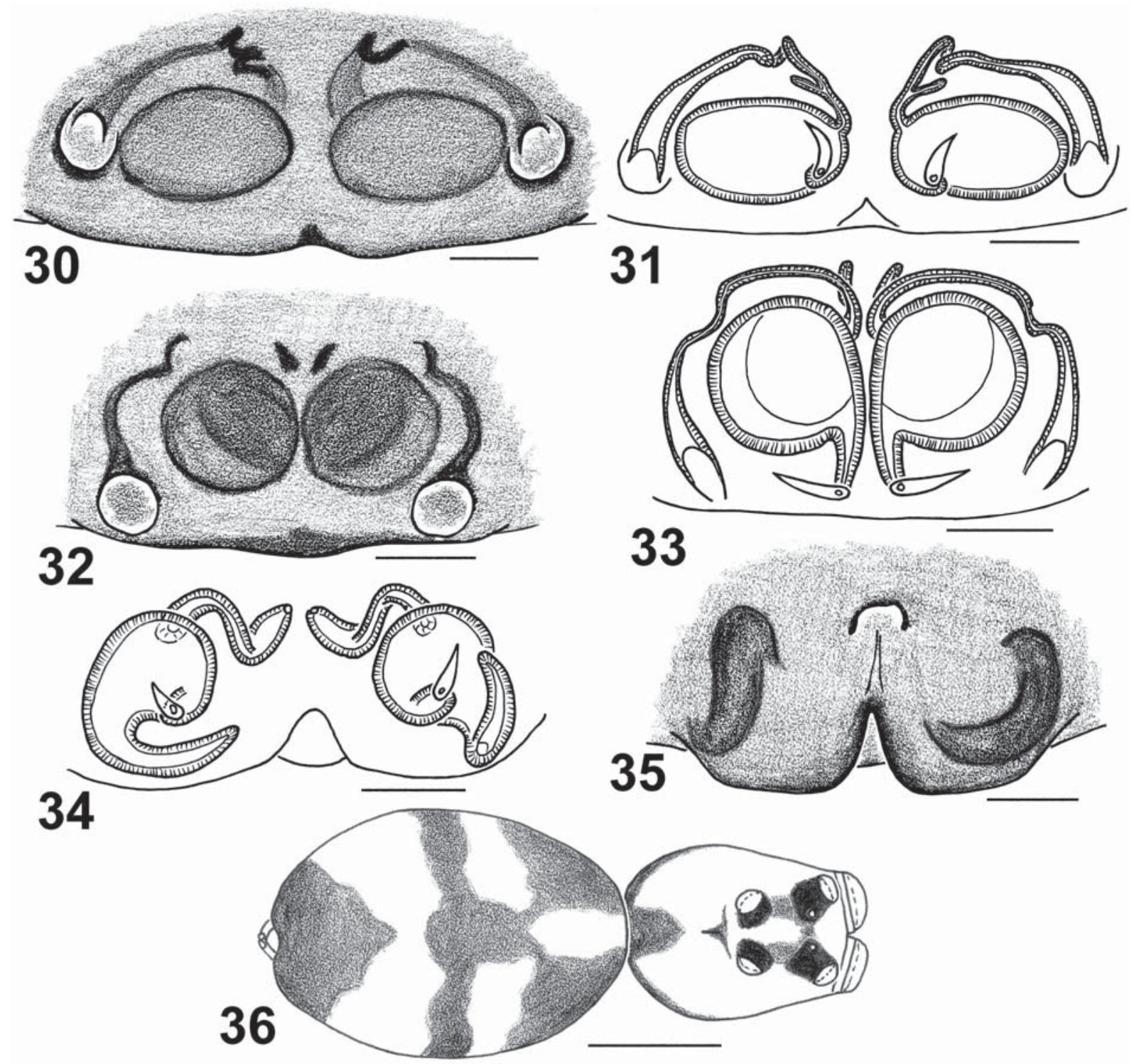

Figs 30-36. Copulatory organs and general appearance of Lyssomanes matoensis sp.n. (30-31, the holotype), L. convexus Banks, 1909 (32-33, from La Selva, Costa Rica) and L. manausensis sp.n. (34-36, the holotype): 30, 32, 35 - epigyne, ventral view; 31, 33, 34 - vulva, dorsal view; 36 - female, dorsal view. Scale bars: $0.1 \mathrm{~mm}(30-35), 1 \mathrm{~mm}(36)$.

Рис. 30-36. Копулятивные органы и внешний вид Lyssomanes matoensis sp.n. (30-31, голотип), L. convexus Banks, 1909 (32-33, из Ля Селвы, Коста-Рика) и L. manausensis sp.n. (34-36, голотип): 30, 32, 35 - эпигина, вид снизу; 31, 33, 34 - вульва, вид сверху; 36 - самка, вид сверху. Масштаб: 0,1 мм (30-35), 1 мм (36).

palps yellow. Carapace blackened around ALEs, PMEs and PLEs, eye field with white scales. Abdomen with no colour pattern. Epigyne and vulva as in Figs 30-31: copulation openings small and round, situated laterally on the epigynal plate, far away from each other; small epigynal pocket present; insemination ducts thin and curving; receptacles transversely-ovoid.

\section{Lyssomanes mexicanus sp.n.}

Figs 37-39.

TYPE MATERIAL. HOLOTYPE $\sigma^{7}(\mathrm{MCZ}, 77394)$ from Mexico, Veracruz, c. $7 \mathrm{~km} \mathrm{~N}$ of Huatusco on HWY 125 (c. $19^{\circ} 12^{\prime} \mathrm{N}$, $96^{\circ} 54^{\prime}$ W), c. $3400 \mathrm{ft}$ a.s.1., 21-22.06.1983, W. Maddison, R.S. Anderson \& M. Kaulbars.

ETYMOLOGY. The species is named after the country of origin, Mexico.

DIAGNOSIS. The male of this species is most close to L. anchicaya from Central America (see above; Figs 1-3) and L. taczanowskii Galiano, 1980 known from a number of Neotropical countries [see Galiano, 1980: figs 41-43; Logunov \& Marusik, 2003: 41-43], but can be distinguished from both by the thicker embolus with a large obtuse basal outgrowth (Fig. 37; absent in both related species) and the shape of median apophysis (Fig. 39). 

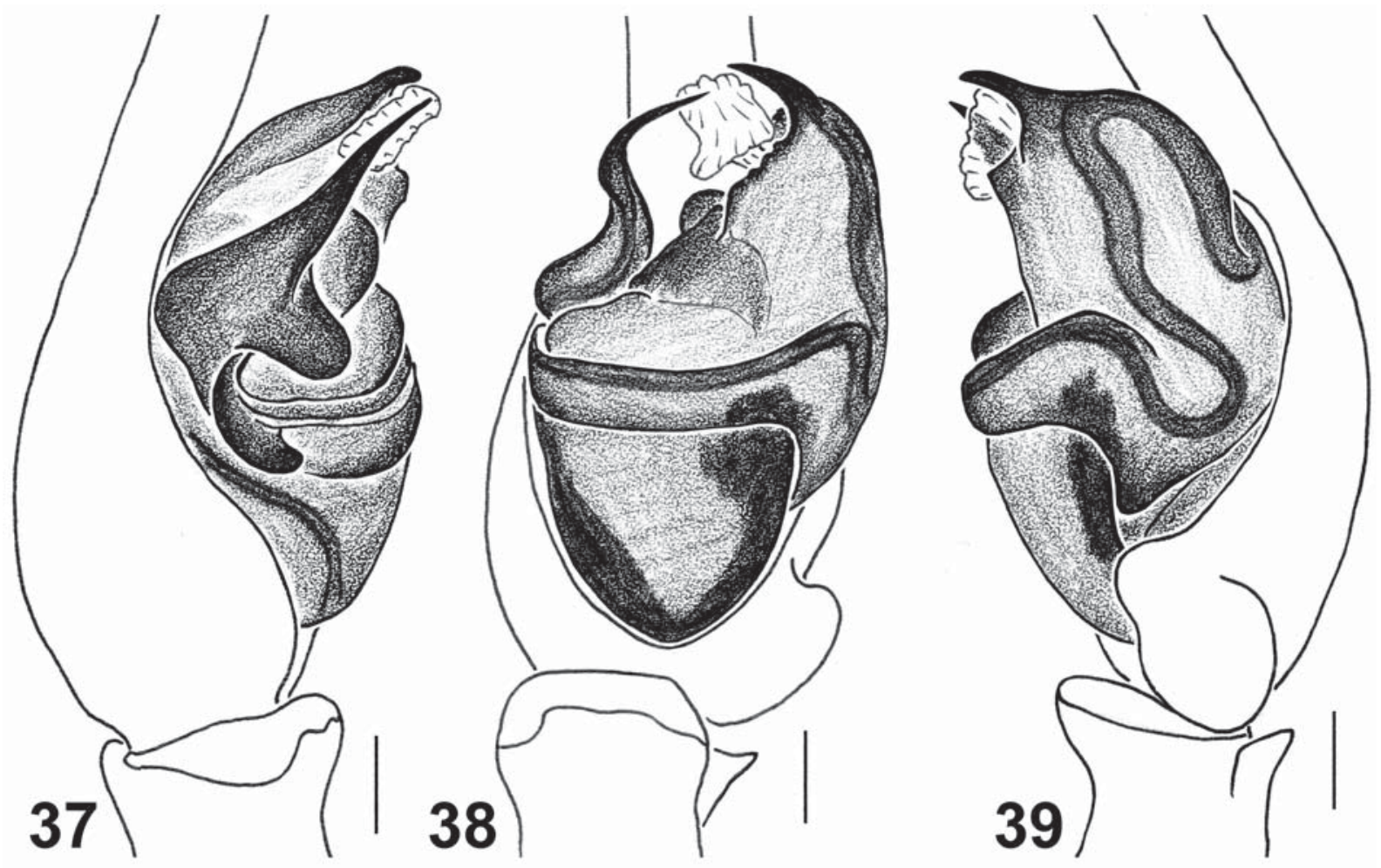

Figs 37-39. Copulatory organs of Lyssomanes mexicanus sp.n. (the holotype): 37 - male palp, prolateral view; 38 - ditto, ventral view; 39 - ditto, retrolateral view. Scale bars: $0.1 \mathrm{~mm}$.

Рис. 37-39. Копулятивные органы Lyssomanes mexicanus sp.n. (the holotype): 37 - пальпа самца, вид пролатерально; 38 тоже, вид снизу; 39 - тоже, вид ретролатерально. Масштаб: 0,1 мм.

DISTRIBUTION. The type locality only: Mexico, Veracruz.

DESCRIPTION. Male. Measurements. Carapace 2.20 long, 1.80 wide, 1.10 high at PLE. Ocular area 1.13 long; width of eye rows: AME-AME-row 1.03, ALE-ALE-row 1.10, PLE-PLE-row 0.83. Diameter of AME 0.53. Abdomen 3.15 long, 1.00 wide. Cheliceral length 1.30. Clypeal height 0.13. Length of leg segments: I $2.65+0.95+2.75+2.65+0.55$; II $2.45+$ $0.85+2.05+2.05+0.50 ;$ III $2.20+0.70+1.80+2.05$ +0.55 ; IV $2.20+0.60+1.85+2.30+0.55$. Leg spination: I: Fm d 1-1-1, pr and rt 0-1-1; Tb d 0-0-1, pr and rt 1-1, v 3 pairs; Mt pr and rt 1-0-0, v 3 pairs. II: Fm d 1-1-1, pr 0-1-1, rt 0-1-0; Pt d 1ap; Tb d, pr and rt 1-1, v 3 pairs; Mt pr and rt 1-0-0, v 3 pairs. III: Fm d 11-1, pr and rt 0-1-1; Pt d 1ap; Tb d 0-1, pr and rt 1-1, v 1-2; Mt pr 1-0-0, rt 1-1-0, v 2-0-0. IV: Fm d and pr 0-11, rt 0-0-1; Pt d 1ap; Tb d 2-0-1, pr and rt 1-1; Mt pr and $v$ 1-0-0. Coloration (in alcohol), the specimen is in poor condition. Body yellow, blackened around ALEs, PMEs and PLEs, and dorsum with two longitudinal grey stripes. Carapace and chelicerae orange. All legs yellow, with brownish Pt and distal parts of Tb. Palps yellow. Palpal structure as in Figs 37-39: cymbium with medium-sized tutaculum; median apophysis wide, with pointed tip and visibly serrated prolateral edge; conductor mushroom-shaped; embo- lus stiletto-shaped, with wide basal outgrowth directed ventrad.

Female unknown.

Lyssomanes reductus Peckham et Peckham, 1896 Figs 40-46.

Lyssomanes reductus Peckham et Peckham, 1896: 100 (D $\left.{ }^{7}\right)$. Lyssomanes simplicipes F.O. Pickard-Cambridge, 1900: 183, pl. 13, fig. $4\left(\mathrm{D} \mathrm{O}^{7}\right)$.

Lyssomanes reductus: Galiano, 1980: 60, figs 82-86 $\left(\sigma^{7}\right)$. Synonymized $L$. simplicipes with $L$. reductus.

MATERIAL. MEXICO: $1 \sigma^{7}, 1$ (MCZ, 77390), Chiapas, c. $76 \mathrm{~km} \mathrm{~S}$ of Palenque on road to Ocosingo (c. $\left.17.1^{\circ} \mathrm{N}, 92.2^{\circ} \mathrm{W}\right)$, forest edge and roadside, 5.07.1983, W. Maddison; $1 \sigma^{7}, 3$ juv. (MCZ, 77374), Veracruz, c. $6 \mathrm{~km} \mathrm{NE}$ of Coscomatepec on HWY 125 (c. $\left.19^{\circ} 07^{\prime} \mathrm{N}, 97^{\circ} 02^{\prime} \mathrm{W}\right)$, c. $3500 \mathrm{ft}$ a.s.1., 22.06.1983, W. Maddison, R.S. Anderson \& M. Kaulbars.

DIAGNOSIS. By the conformation of palp, the male is most similar to those of $L$. remotus Peckham et Peckham, 1896 and L. mandibulatus F.O. PickardCambridge, 1900 [cf. Galiano, 1980: figs 92-97; Logunov \& Marusik, 2003: figs 22-24], but can be easily distinguished from the former by hook-shaped embolus (not straight as in L. remotus) and from the latter by the shape of markedly bent median apophysis (Figs 4142). By the presence of median septum of epigyne (Fig. 45), the female is rather similar to that of $L$. tarmae Galiano, 1980 from Peru [cf. Galiano, 1980: 

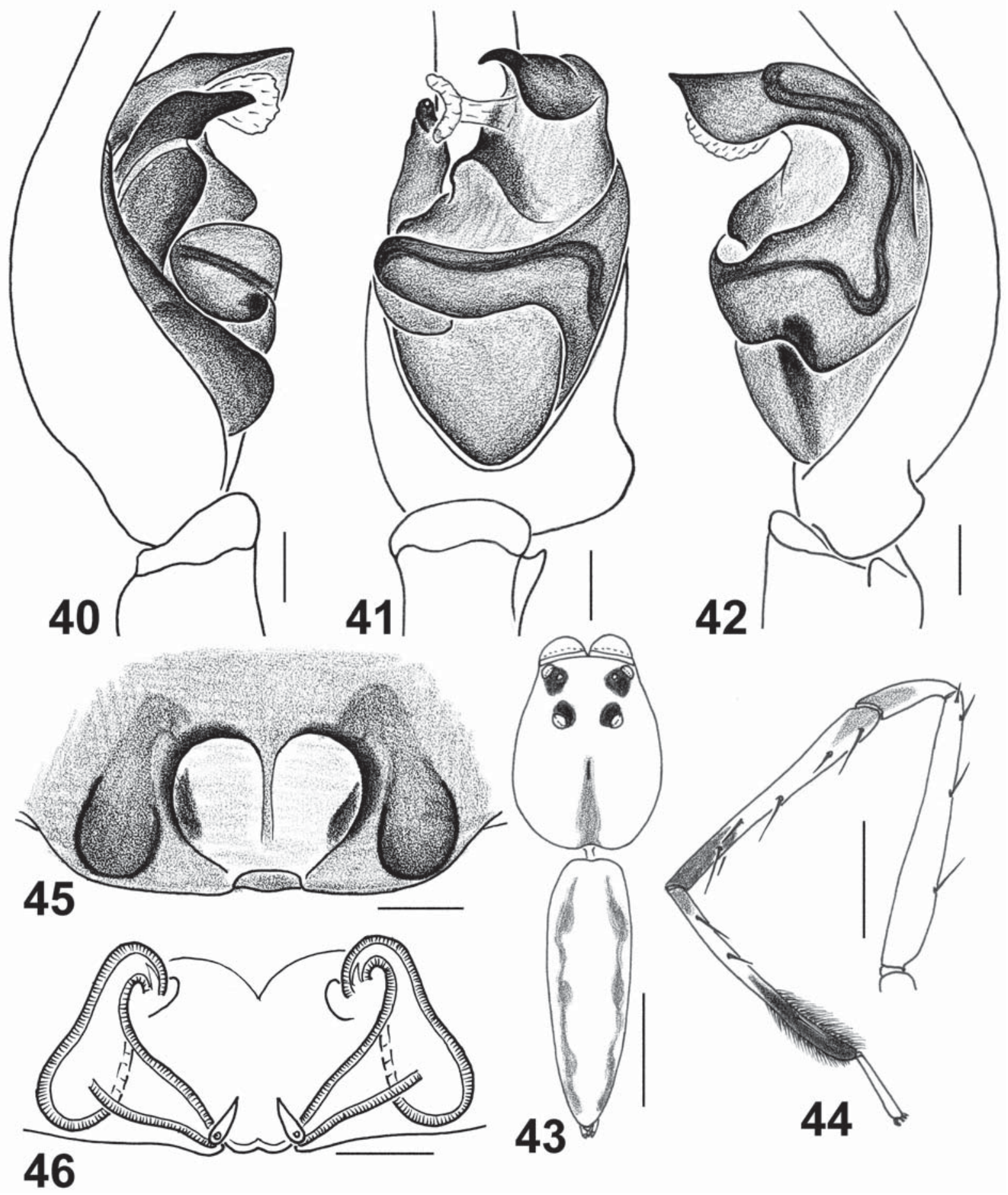

Figs 40-46. Copulatory organs and somatic characters of Lyssomanes reductus Peckham et Peckham, 1896 ( $\sigma^{7}$ from Veracruz, Mexico, f from Chiapas, Mexico): 40 — male palp, prolateral view; 41 — ditto, ventral view; 42 — ditto, retrolateral view; 43 - male general appearance, dorsal view; 44 - male leg I, lateral view; 45 - epigyne, ventral view; 46 — vulva, dorsal view. Scale bars: $0.1 \mathrm{~mm}$ (40-42, 45-46), $1 \mathrm{~mm}(43-44)$.

Рис. 40-46. Копулятивные органы и соматические признаки Lyssomanes reductus Peckham et Peckham, 1896 (○’ из Веракрус, Мексика, + из Чьяпас, Мексика): 40 - пальпа самца, вид пролатерально; 41 - тоже, вид снизу; 42 - тоже, вид ретролатерально; 43 - внешний вид самца, вид сверху; 44 - нога I самца, вид сбоку; 45 - эпигина, вид снизу; 46 - вульва, вид сверху. Масштаб: 0,1 мм (40-42, 45-46), 1 мм (43-44). 
figs 165-166], from which it can be distinguished by the receptacles consisting of two sections (Fig. 46). The female of L. reductus is found and described for the first time.

DISTRIBUTION. To date this species has been known from Mexico, Guatemala, Honduras and Panama [Galiano, 1980; present data]. New record for Mexico.

DESCRIPTION. Male (MCZ, 77374). Measurements. Carapace 1.95 long, 1.45 wide, 1.20 high at PLE. Ocular area 0.88 long; width of eye rows: AMEAME-row 0.85, ALE-ALE-row 0.80, PLE-PLE-row 0.61. Diameter of AME 0.41. Abdomen 2.55 long, 0.85 wide. Cheliceral length 1.10 . Clypeal height 0.14 . Length of leg segments: I $2.50+0.78+2.30+2.25+$ 0.55 ; II $2.08+0.70+1.75+1.78+0.55$; III $1.95+$ $0.60+1.65+1.85+0.55 ;$ IV $1.95+0.55+1.75+2.13$ +0.55 . Leg spination: I: Fm d 1-1-1, pr and rt 0-1-1; Tb pr and rt 1-1, v 3 pairs; Mt pr and rt 1-0-0, v 3 pairs and dorsal and ventral rows of dark brown hairs (Fig. 44). II: Fm d 1-1-1, pr and rt 0-1-1; Pt d 1ap; Tb d, pr and rt 1-1, v 3 pairs; Mt pr and rt 1-0-0, v 3 pairs. III: Fm d 1-1-1, pr and rt 0-1-1; Pt d 1ap; Tb d, pr and rt 11, v 0-1; Mt pr and rt 1-1-0. IV: Fm d 1-1-1, rt 0-0-1; Pt d 1ap; Tb d, pr and rt 1-1, Mt pr 0-1-0. Coloration (in alcohol). Carapace yellow-orange, with blackened around ALEs, PMEs and PLEs, and median dark grey stripe (Fig. 43). Sternum, labium and maxillae yellow. Chelicerae yellow-orange. Abdomen yellow, but dorsum with two longitudinal grey stripes (Fig. 43). All legs yellow, with brownish semi-rings at segment joints (Pt/Tb, Tb/Mt and Mt/Tr; Fig. 44). Legs I also bear rows of dorsal and ventral hairs. Palps yellow. Palpal structure as in Figs 40-42: median apophysis as a wide hook; conductor mushroom-shaped; embolus thick and singular; and cymbium with medium-sized tutaculum.

Female (MCZ, 77390). Measurements. Carapace 2.50 long, 1.75 wide, 1.20 high at PLE. Ocular area 1.00 long; width of eye rows: AME-AME-row 1.05, ALE-ALE-row 0.98, PLE-PLE-row 0.74. Diameter of AME 0.50. Abdomen 3.00 long, 1.20 wide. Cheliceral length 1.03. Clypeal height 0.13 . Length of leg segments: I $2.35+0.98+2.20+2.00+0.55$; II $2.20+$ $0.88+0.95+1.80+0.55 ;$ III $2.25+0.83+1.73+1.95$ $+0.60 ;$ IV $2.05+0.70+1.85+2.25+0.55$. Leg spination: I: Fm d 1-1-1, pr and rt 0-1-1; Tb pr 0-1, rt 11, v 4 pairs; Mt pr and rt 1-0-0, v 3 pairs. II: Fm d 1-11, pr and rt 0-1-1; Tb pr and rt 1-1, v 3 pairs; Mt pr and rt 1-0-0, v 3 pairs. III: Fm d 1-1-1, pr and rt 0-1-1; Pt d 1ap; Tb d, pr and rt 1-1, v 0-2; Mt pr and rt 1-1-0, v 22-0. IV: Fm d 1-1-1, pr 0-0-1; Pt d 1ap; Tb d and pr 11, rt 0-1; Mt pr and v 0-1-0. Coloration (in alcohol). Entire body, all legs and palps yellow. Abdomen with no colour pattern. Blackened around ALEs, PMEs and PLEs, plus eye field with white scales. Epigyne and vulva as in Figs 45-46: epigyne with the central atrium subdivided by a narrow median septum into two fossae; insemination ducts very short; receptacles consist of two sections.

\section{Lyssomanes silvestris sp.n.}

Figs 49-50.

TYPE MATERIAL. Holotype + (MCZ, 77465) from Brazil, Mato Grosso, c. $260 \mathrm{~km} \mathrm{~N}$ of Xavantina $\left(12^{\circ} 49^{\prime} \mathrm{S}, 51^{\circ} 46^{\prime} \mathrm{W}\right)$, gallery forest, 30.11.1968, expedition Xavantina-Cachimbo.

ETYMOLOGY. The species epithet originates from the Latin word 'silvestris' meaning 'pertaining to a wood', 'woody'.

DIAGNOSIS. This species has a unique conformation of its copulatory organs (viz., the shape of shallow atrium and the enema-shaped receptacles; Figs 49-50) that are different from those of all the Lyssomanes species known to me.

DISTRIBUTION. The type locality only.

DESCRIPTION. Female. Measurements. Carapace 3.10 long, 2.45 wide, 1.50 high at PLE. Ocular area 1.68 long; width of eye rows: AME-AME-row 1.48, ALE-ALE-row 1.50, PLE-PLE-row 1.08. Diameter of AME 0.58. Abdomen 4.30 long, 1.60 wide. Cheliceral length 1.25. Clypeal height 0.25 . Length of leg segments: I $3.40+1.30+3.30+3.45+0.75$; II $3.10+$ $1.15+2.85+2.85+0.70 ;$ III $2.90+1.05+2.48+3.00$ +0.80 ; IV $2.80+0.85+2.40+3.20+0.80$. Leg spination: I and II: Fm d 1-1-1, pr and rt 0-1-1; Pt d 1ap; Tb pr and rt 0-1, v 4 pairs; Mt pr and rt 1-0-0, v 3 pairs. III: Fm d 1-1-1, pr and rt 0-1-1; Pt d 1ap; Tb d, pr and rt 0-1, v 2-2; Mt pr and rt 1-0-0, v 2-2-1ap. IV: Fm d 1-1-2; Pt d 1ap; Tb d 0-1, pr and rt 1-1, Mt pr 1-1$1 \mathrm{ap}, \mathrm{rt} 1-0-1 \mathrm{p}, \mathrm{v} 1-0$. Coloration (in alcohol). Entire body, all legs and palps yellow. Carapace blackened around ALEs, PMEs and PLEs, eye field with white scales. Abdomen with no colour pattern. Epigyne and vulva as in Figs 49-50: copulation openings situated inside shallow transverse atrium; epigynal pocket absent; relatively short, tube-like, S-shaped insemination ducts and enema-shaped receptacles.

\section{Lyssomanes similis sp.n.}

Figs 47-48.

TYPE MATERIAL. Holotype $q$ (MCZ, 77436) from Brazil, c. $80 \mathrm{~km}$ N of Manaus, Cabo Frio Reserve, 13.10.1989, H.G. Fowler.

Paratype: 1 ( $(\mathrm{MCZ}, 77464)$, Brazil, Mato Grosso, c. $260 \mathrm{~km}$ $\mathrm{N}$ of Xavantina $\left(12^{\circ} 49^{\prime} \mathrm{S}, 51^{\circ} 46^{\prime} \mathrm{W}\right), 30.11 .1968$, expedition Xavantina-Cachimbo.

ETYMOLOGY. The species epithet is derived from the Latin word 'similis', meaning 'resembling'.

DIAGNOSIS. Based on Galiano's [1980] grouping, this species belongs to the robustus group and is most similar to L. jucari Galiano, 1984 from Brazil [see Galiano, 1984: figs 33-34], L. lehtineni Logunov, 2000 from Peru [Logunov, 2000a: figs 1-2] and a rather common species L. taczanowskii [see Galiano, 1980: figs 44-45; Logunov \& Marusik, 2003: 44-45], from which it can readily be distinguished by the longer insemination ducts having a markedly different, Sshaped conformation (Fig. 48).

DISTRIBUTION. Two localities in Brazil: Cabo Frio Reserve and Mato Grosso. 

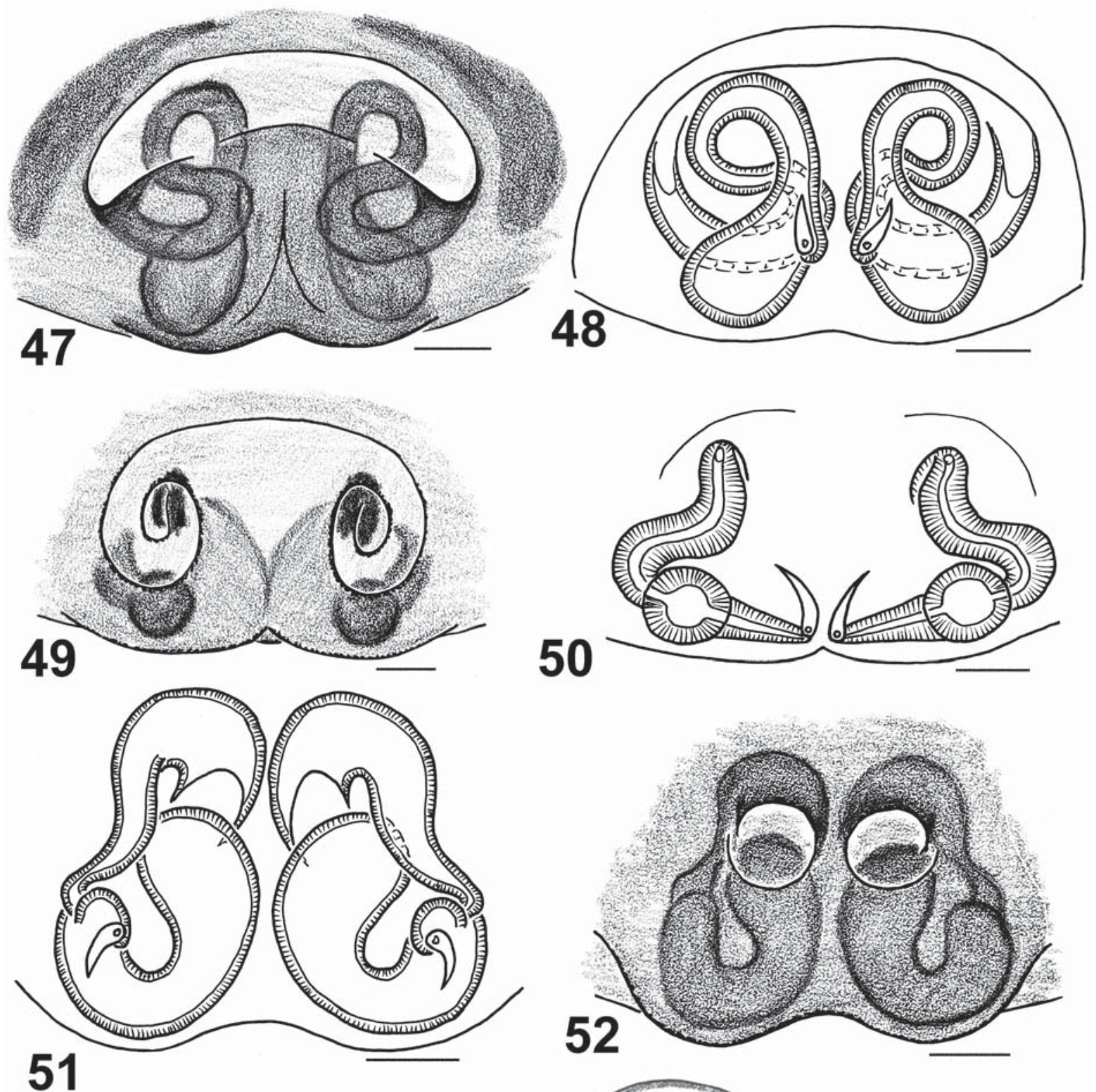

51
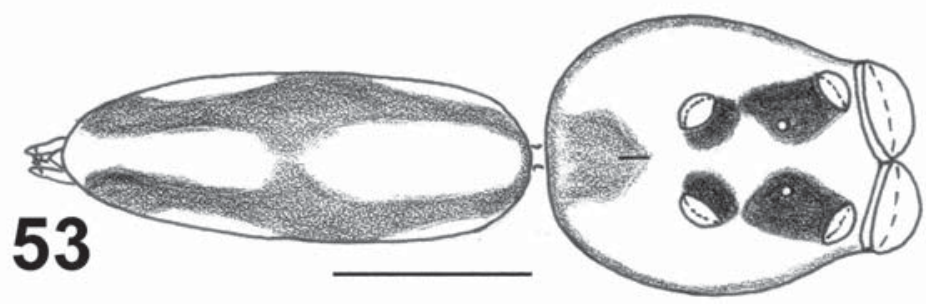

Figs 47-53. Copulatory organs and general appearance of Lyssomanes similis sp.n. (47-48, the holotype), L. silvestris sp.n. (49-50, the holotype) and L. vinocurae Galiano, 1996 (51-53, from Santarem, Brazil): 47, 49, 52 - epigyne, ventral view; 48, 50, 51 - vulva, dorsal view; 53 - female, dorsal view. Scale bars: $0.1 \mathrm{~mm}(30-35), 1 \mathrm{~mm}(36)$.

Рис. 47-53. Копулятивные органы и внешний вид Lyssomanes similis sp.n. (47-48, голотип), L. silvestris sp.n. (49-50, голотип) и L. vinocurae Galiano, 1996 (51-53, из Сантарем, Бразилия): 47, 49, 52 - эпигина, вид снизу; 48, 50, 51 — вульва, вид сверху; 53 - самка, вид сверху. Масштаб: 0,1 мм (30-35), 1 мм (36). 
DESCRIPTION. Female (the holotype). Measurements. Carapace 2.70 long, 2.15 wide, 1.55 high at PLE. Ocular area 1.70 long; width of eye rows: AME-AMErow 1.38, ALE-ALE-row 1.40, PLE-PLE-row 1.05. Diameter of AME 0.58. Abdomen 4.60 long, 2.80 wide. Cheliceral length 1.30. Clypeal height 0.25 . Length of leg segments: I $3.60+1.25+3.30+3.18+0.80$; II 3.25 $+1.05+2.80+2.88+0.75 ;$ III $3.00+0.95+2.60+$ $3.20+0.80 ;$ IV $2.95+0.80+2.75+3.65+0.75$. Leg spination: I: Fm d 1-1-1, pr and rt 0-1-1; Tb d 0-0-1, v 5 pairs; Mt pr and rt 1-0-0, v 3 pairs. II: Fm d 1-1-1, pr and rt 0-1-1; Pt d 1ap; Tb d 1-0-1, v 5 pairs; Mt pr and rt 1-00 , v 3 pairs. III: Fm d 1-1-1, pr and rt 0-1-1; Pt d 1ap; Tb d 0-1, pr and rt 1-1, v 0-2-0; Mt d 2-1-0, v 2-2-0. IV: Fm d 1-1-1, pr and rt 1ap; Pt d 1ap; Tb d, pr and rt 1-1, v 01; Mt pr and rt 1-1-0, v 0-1-0. Coloration (in alcohol). Entire body, all legs and palps yellow. Carapace blackened around ALEs, PMEs and PLEs, eye field with white scales. Abdomen with no colour pattern. Epigyne and vulva as in Figs 47-48: copulation openings are widely spaced and situated in a shallow transverse atrium; epigynal pocket absent; long, S-shaped insemination ducts and oval receptacles.

\section{Lyssomanes vinocurae Galiano, 1996}

Figs 51-53,

Lyssomanes vinocurae Galiano, 1996: 24, figs 1-7 (D $\sigma^{7}+$ ).

MATERIAL. BRAZIL: 2 우, 1 juv. (MCZ, 77512), Santarem, no date, Moenkhaus; $1+(\mathrm{MCZ}, 77514)$, no exact locality, date and collector, Peckhams collection.

DIAGNOSIS. This species is most similar to $L$. tenuis Peckham, Peckham et Wheeler, 1889, a relatively widespread Neotropical species (see below), from which the female can easily be distinguished by the proportions of receptacles and the much shorter insemination ducts (Fig. 51; cf. Galiano [1980: figs 8-9]). The male of $L$. vinocurae was diagnosed by Galiano [1996].

COMMENTS. The proportion of receptacles of the studied female (MCZ, 77512; Fig. 51) slightly differs from that of the paratype [Galiano, 1996: fig. 6], which is my opinion reflects a variation of this character only. Yet, the body coloration (Fig. 53) and size fit ideally to the original description [cf. Galiano, 1996: figs 3-4].

DISTRIBUTION. A few localities in Brazil only [Galiano, 1996; Logunov, 2002; present data].

DESCRIPTION. Male, see Galiano [1996].

Female (MCZ, 77512). Measurements. Carapace 1.90 long, 1.40 wide, 0.98 high at PLE. Ocular area 1.28 long; width of eye rows: AME-AME-row 0.98, ALE-ALE-row 0.95, PLE-PLE-row 0.75. Diameter of AME 0.50. Abdomen 2.40 long, 0.90 wide. Cheliceral length 0.68 . Clypeal height 0.10 . Length of leg segments: I $2.45+0.75+2.2 .5+2.20+0.55$; II $2.05+$ $0.65+1.75+1.75+0.55 ;$ III $1.85+0.60+1.60+1.90$ +0.55 ; IV $2.15+0.50+1.80+2.40+0.55$. Leg spination (the specimen is in poor condition, spines are absent from some segments): I and II: Fm d 1-1-1, pr and rt 0-1-1; Tb v 5 pairs; Mt v 3 pairs. III: Fm d 1-1-1; Pt d 1ap; Tb pr and rt 0-0-1; Mt pr and rt 0-1-0. IV: Fm d 1-1-1; Pt d 1 ap; Tb and Mt without spines. Coloration (in alcohol, the illustrated $q$, in poor condition). Carapace yellow, with a dark grey marginal line and a wide median band on thorax (Fig. 53), blackened around ALEs, PMEs and PLEs, eye field with white scales. Sternum, labium, maxillae and chelicerae yellow. Abdomen yellow, with two longitudinal stripes on dorsum as shown in Fig. 53. Legs I and II yellow, with grey pro- and retrolateral stripes on femora and coxae I. Legs III and IV entirely yellow. Palps yellow. Epigyne and vulva as in Figs 51-52: large copulation openings situated close to each other; epigynal pocket absent; wide, tube-like insemination ducts and bean-shaped receptacles.

\section{New faunistic records}

Lyssomanes amazonicus Peckham, Peckham et Wheeler, 1889

MATERIAL. GUYANA: $1 \sigma^{7}$ (ONHM), “...long leaf on road Kanganuna, 8/8/595, B.G.”, G.P. Lampel [handwritten illegible label]; 1 \& (ONHM), “...wet dawn wallaber (?), Amatuk, 4/8/592/, B.G.”, G.P. Lampel [handwritten label is illegible; apparently from Georgetown, Guyana]. - COLOMBIA: $1 \sigma^{7}$ (MCZ, 77533), Meta, c. $15 \mathrm{~km}$ SW of Puerto Lopez, Had. Mozambique, $500 \mathrm{~m}$ a.s.1., 06.1975, W.G. Eberhard.

COMMENTS. It is a rather common species known to date from Bolivia, Brazil, Guyana and Ecuador [Galiano, 1962, 1980; Logunov, 2002; Logunov \& Marusik, 2003]. New record for Colombia.

Lyssomanes antillanus Peckham, Peckham et Wheeler, 1889

MATERIAL. DOMINICAN REPUBLIC: $1 \sigma^{7}, 1$ ( 1 CZ, 77523, 77524), Sanchez Ramirez (Cotui), Mina Pueblo Viejo, nr. Hatillo, c. $500 \mathrm{~m}$ a.s.1., 21.03.1984, H. \& L. Levi; 6 O$^{\top} \sigma^{7}, 1$ 古 (MHNG), Colonia Cord. Centr., $100 \mathrm{~m}$ a.s.1., 21.04-3.06.1972, J. \& S. Klapperich; 1 ( $(\mathrm{MHNG})$, Colonia Cord. Centr., $1250 \mathrm{~m}$ a.s.1., 7.07.1972, J. \& S. Klapperich; 1 क (MCZ, 77463), Loma Fría, Sierra Martín García, c. 1200 m a.s.1, 1.08.1983, G. Flores. JAMAICA: $3 \sigma^{7} \sigma^{7}, 1$ ㅇ (MCZ, 77486, 77475, 77470), Westmoreland, Negril, 23-30.03.1981, H. \& L. Levi; $2 \sigma^{\top} \sigma^{\top}, 1$ 우 (MCZ, 77494), St. Andrew Parish, Kingston, buildings \& garden, 21.03.1972, H. \& F. Levi; 1 9 (MCZ, 77499), Surrey, Bath, 1.04. 1937, coll.?. - CARRIBEAN NETHERLANDS: 1 (MCZ, 77496), Saba [island], 1973, H.A. Beatty. - CUBA: $2 \sigma^{\top} \sigma^{\top}, 1$ 우 (MCZ, 77503), no exact locality, 1967, P. Alayo; $1 \sigma^{7}$ (MCZ, 77522), Pinar del Río, Sierra del Rosario nr. Institute of Botany research area, 05.1976, R. Levins.

COMMENTS. This species has been recorded to date from the Greater Antilles only (Cuba, Jamaica and Hispaniola) [Galiano, 1962, 1980; present data]. New record for Carribean Netherlands.

Lyssomanes bitaeniatus Peckham, Peckham et Wheeler, 1889

MATERIAL. PANAMA: 1 (MCZ, 77525), Panama Prov., Canal area, Fort Kobbe $\left(8^{\circ} 55^{\prime} \mathrm{N}, 79^{\circ} 34^{\prime} \mathrm{W}\right)$, forest, night collecting, 3.08.1983, H. \& L. Levi, H. Stockwell.

COMMENTS. It is a rather common species known to date from El Salvador to Venezuela [Galiano, 1962, 1980; Logunov \& Marusik, 2003; present data]. 

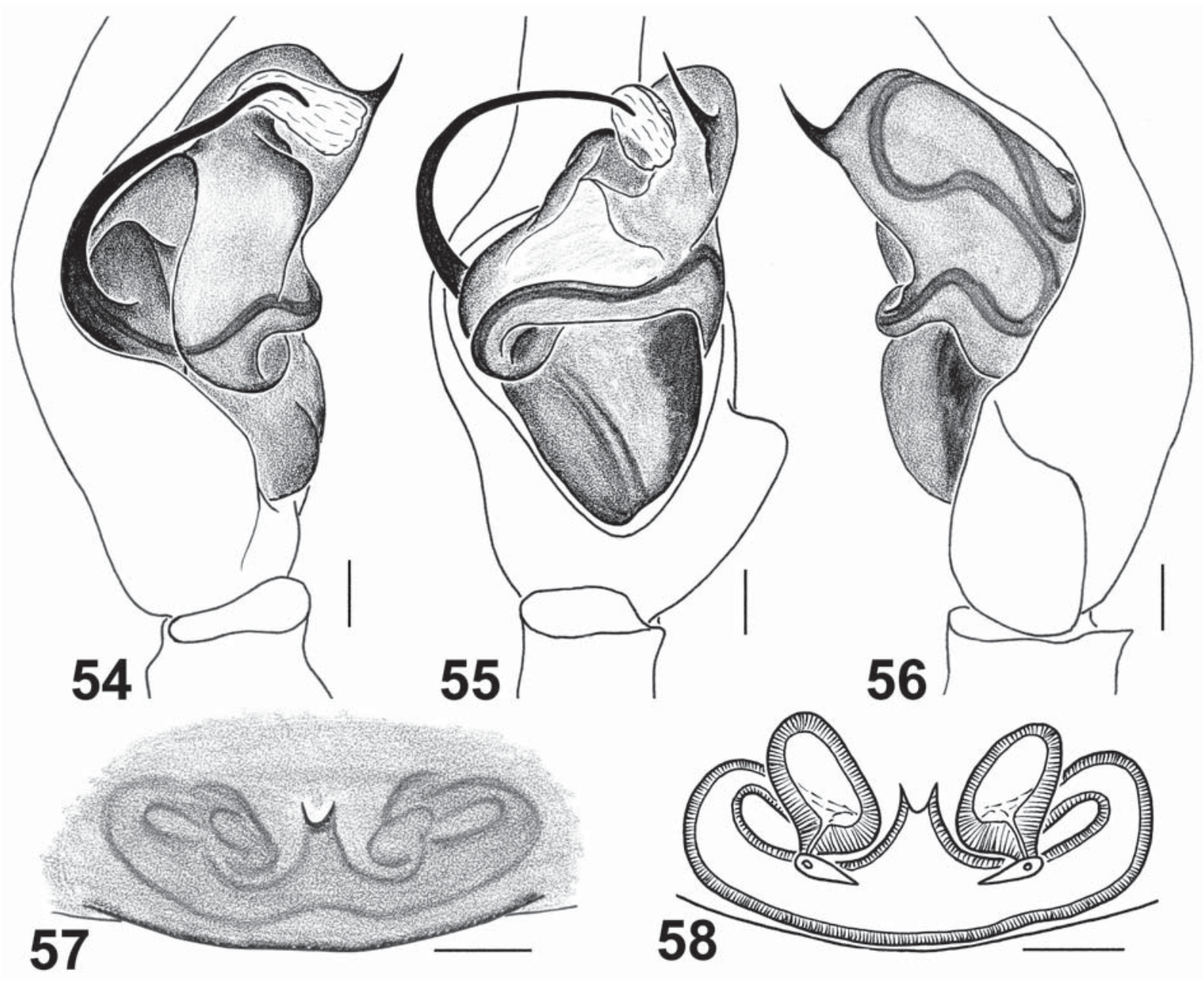

Figs 54-58. Copulatory organs of Lyssomanes leucomelas Mello-Leitão, 1917 ( $0^{7}$ from Rio Grande River, Brazil,, from Sao Paulo, Brazil): 54 - male palp, prolateral view; 55 - ditto, ventral view; 56 - ditto, retrolateral view; 57 - epigyne, ventral view; 58 - vulva, dorsal view. Scale bars: $0.1 \mathrm{~mm}$.

Рис. 54-58. Копулятивные органы Lyssomanes leucomelas Mello-Leitro, 1917 (Ơ с реки Рио Гранде, Бразилия, + из Сан-Паоло, Бразилия): 54 - пальпа самца, вид пролатерально; 55 - тоже, вид снизу; 56 - тоже, вид ретролатерально; 57 - эпигина, вид снизу; 59 - вульва, вид сверху. Масштаб: 0,1 мм. 1900

Lyssomanes consimilis F.O. Pickard-Cambridge,

MATERIAL. PANAMA: $3 \sigma^{7} \sigma^{7}, 2$ 우 (MCZ, 77490, 77495), Panama Prov., Canal Zone, Barro Colorado Island, 15.05.1964, A.M. Chickering.

COMMENTS. To date this species is from Panama only [Chickering, 1946: sub. L. montanus; Galiano, 1980; present data].

Lyssomanes convexus Banks, 1909

Figs 32-33.

MATERIAL. COSTA RICA: 19 (MCZ, 77473), nr. Puerto Viejo, La Selva, c. 50 m a.s.1., 12.1980, W.G. Eberhard.

COMMENTS. To date this species has been found in Costa Rica only and remains known from the females [Galiano, 1980; Logunov \& Marusik, 2003; present data].
Lyssomanes deinognathus F.O. Pickard-Cambridge, 1900

MATERIAL. MEXICO: $1 \mathrm{O}^{\top}, 2$ ㅇ (MCZ, 77388), Campeche, Chicanna ruins, c. $8 \mathrm{~km} \mathrm{~W}$ of Xpujil (c. $\left.18^{\circ} 32^{\prime} \mathrm{N}, 89^{\circ} 31^{\prime} \mathrm{W}\right)$, short tropical rainforest, 12-14.07.1983, W. Maddison; $2 \sigma^{7} \sigma^{7}, 2$ 우 (MCZ, 77377), Campeche, c. $6 \mathrm{~km} \mathrm{~W}$ of Francisco Escarcega 'El Tormento' forest station (c. $\left.18^{\circ} 37^{\prime} \mathrm{N}, 90^{\circ} 48^{\prime} \mathrm{W}\right), 11-12.07 .1983$, W. Maddison; 1 + (MCZ, 77399), Chiapas, c. $105 \mathrm{~km} \mathrm{SE}$ of Palenque on toad to Bonampak (c. $\left.17.0^{\circ} \mathrm{N}, 91.3^{\circ} \mathrm{W}\right)$, tropical rainforest and roadside bushes, 8-9.07.1983, W. Maddison; $10^{7}, 2$ 우오 (MCZ, 77395), Chiapas, Palenque ruins area (c. $17^{\circ} 29^{\prime} \mathrm{N}, 92^{\circ} 01^{\prime} \mathrm{W}$ ), tropical rainforest and edge, 2-11.07.1983, W. Maddison \& R.S. Anderson; 19 (MCZ, 77372), Quintana Roo, Coba ruins (c. 20 ${ }^{\circ}$ $30^{\prime} \mathrm{N}, 87^{\circ} 42^{\prime} \mathrm{W}$ ), 18.07.1983, W. Maddison; $5 \mathrm{O}^{\top} \mathrm{O}^{\prime}, 5$ 우 (MCZ, 77375), Quintana Roo, Kohunlich ruins $9 \mathrm{~km} \mathrm{~S}$ of Francisco Villa (c. $18^{\circ} 26^{\prime} \mathrm{N}, 88^{\circ} 48^{\prime} \mathrm{W}$ ), cohune palm forest and clearings, 14 17.07.1983, W. Maddison \& R.S. Anderson; 1 + (MCZ, 77387), Quintana Roo, c. $31 \mathrm{~km}$ NE of Felippe Carrillo Puerto on HWY 307 toward Tulum (c. $\left.19^{\circ} 48^{\prime} \mathrm{N}, 87^{\circ} 52^{\prime} \mathrm{W}\right), 17.07 .1983$, W. Maddison \& R.S. Anderson. 
COMMENTS. To date this species has been recorded from Mexico and Honduras only [Galiano, 1980; present data].

Lyssomanes elegans F.O. Pickard-Cambridge, 1900

MATERIAL. BELIZE: $1 \sigma^{\top}$ (MMUM), Las Cuevas research station, 24.06.2006, E. Shaw.

COMMENTS. It is a rather common species known to date from southern Mexico to south-eastern Brazil [Chickering, 1946: sub L. zeteki; Galiano, 1980; Logunov, 2002; present data]. New record for Belize.

Lyssomanes jemineus Peckham, Peckham et Wheeler, 1889

MATERIAL. COSTA RICA: $2 \mathrm{O}^{7} \mathrm{O}^{7}$ (MCZ, 77468, 77476), San José, in house, 2.07.1994, R.L. Rodriguez; $10^{7}, 1 \%$ (MCZ, 77531), San José, San Antonio de Escazu, c. $1300 \mathrm{~m}$ a.s.l., 21.06.1981, W.G. Eberhard; 1 + (MCZ, 77529), Canas, La Pacifica, 1.07.1976, no collector name; 1 ơ (MCZ, 77530), San José, San Antonio de Escazu, c. 1300 m a.s.1., 07.1981, W.G. Eberhard; $1 O^{7}$ (MCZ, 77526), same locality, no date and collecto name. - GUATEMALA: 1 (BMNH), El Estor, 30.04.1978, P Embden. - GUYANA: 1 ㅇ (BMNH), "British Guiana" (no exact locality), June 1938, C.A. Hudson. - COLOMBIA: $10^{7}, 4$ 우우, 2 juv. (MCZ, 77491, 77492, 77493), Valle, Cali, $1000 \mathrm{~m}$ a.s.1., around house, 1973-1974, W.G. Eberhard; $20^{7} \sigma^{7}, 1$ juv. (MCZ, 77487), same locality, 1976, W.G. Eberhard; 1 \& (MCZ, 77506), same locality, 1969, W.G. Eberhard; $10^{7}$ (MCZ, 77509), same locality, 1977, W.G. Eberhard. - MEXICO: $10^{7}, 3$ 우 (MCZ, 77383), Chiapas, c. $71 \mathrm{~km} \mathrm{~S}$ of Palenque on road to Ocosingo (c $\left.17.2^{\circ} \mathrm{N}, 92.2^{\circ} \mathrm{W}\right), 5.07 .1983$, W. Maddison; $30^{7} \sigma^{7}, 1$ 오 (MCZ, 77391, 77397), Chiapas, c. $76 \mathrm{~km} \mathrm{~S}$ of Palenque on road to Ocosingo (c. $17.1^{\circ} \mathrm{N}, 92.2^{\circ} \mathrm{W}$ ), c. $2500 \mathrm{ft}$ a.s.1., forest edge \& roadside, 5-29.07.1983, W. Maddison; 1 + (MCZ, 77381), Chiapas, c. $6 \mathrm{~km} \mathrm{SW}$ of Ocosingo on road to Oxchuc (c. $16.9^{\circ} \mathrm{N}$, $92.2^{\circ} \mathrm{W}$ ), c. $3500 \mathrm{ft}$ a.s.1., 29.07.1983, W. Maddison; 1 ㅇ (MCZ, $77373,77384)$, Campeche, c. $6 \mathrm{~km} \mathrm{~W}$ of Francisco Escarcega, 'El Tormento' forest station (c. $\left.18^{\circ} 37^{\prime} \mathrm{N}, 90^{\circ} 48^{\prime} \mathrm{W}\right), 11-23.07 .1983$, W. Maddison; $9 \sigma^{7} \sigma^{7}, 10$ 우 (MCZ, 77516, 77382), Campeche, Chicanna ruins, c. $8 \mathrm{~km} \mathrm{~W}$ of Xpujil (c. $\left.18^{\circ} 32^{\prime} \mathrm{N}, 89^{\circ} 31^{\prime} \mathrm{W}\right)$, short tropical rainforest, 12-14.07.1983, W. Maddison; 1 क (MCZ, $77401)$, San Luis Potosi, El Salto de Agua (c. $22^{\circ} 35^{\prime} \mathrm{N}, 99^{\circ} 21^{\prime} \mathrm{W}$ ) 8.06.1983, W. Maddison; 3 O$^{7} \sigma^{7}, 2$ 우 (MCZ, 77398), San Luis Potosi, nr. Taman, c. $16 \mathrm{~km} \mathrm{SW}$ of Tamazunchale on HWY 85 (c. $\left.21^{\circ} 11^{\prime} \mathrm{N}, 98^{\circ} 53^{\prime} \mathrm{W}\right)$, c. $1000 \mathrm{ft}$ a.s.1., 11.06 .1983 , W. Maddison; 1 (MCZ, 77386), Quintana Roo, c. $31 \mathrm{~km} \mathrm{NE}$ of Felipe Carrillo Puerto on HWY 307 toward Tulum (c. $\left.19^{\circ} 48^{\prime} \mathrm{N}, 82^{\circ} 52^{\prime} \mathrm{W}\right), 17.07$ 1983, W. Maddison \& R.S. Anderson; 1 + (MCZ, 77389), Oaxaca, c. $2 \mathrm{~km} \mathrm{~S}$ of El Tule (c. $17^{\circ} 02^{\prime} \mathrm{N}, 96^{\circ} 40^{\prime} \mathrm{W}$ ), $5000 \mathrm{ft}$ a.s.1., scrub of Acacia, bushes, composites \& short grass, 4-5.08.1983, W. Maddison \& R.S. Anderson; $1 O^{7}$ (MCZ, 77379), Oaxaca, Temascal (c. $\left.18^{\circ} 14^{\prime} \mathrm{N}, 96^{\circ} 25^{\prime} \mathrm{W}\right), 300 \mathrm{ft}$ a.s.l., 2 nd growth forest edge, 24.08.1983, W. Maddison; $4 \mathrm{O}^{\top} \mathrm{O}^{\top}, 1$ 우 (MCZ, 77376), Tamaulipas, Naciemente del Rio Frio, nr. Gomez Farias (c. $23.1^{\circ} \mathrm{N}$, $\left.91.1^{\circ} \mathrm{W}\right), 6-7.06 .1983$, W. Maddison; $10^{7}$ (MCZ, 77378), Yukatan, c. $3 \mathrm{~km}$ E of Chichen Itza ruins on HWY 180 (c. $20^{\circ} 40^{\prime} \mathrm{N}$, $\left.88^{\circ} 34^{\prime} \mathrm{W}\right), 19-20.07 .1983$, W. Maddison \& R.S. Anderson; $10^{7}$, 1 ( (MCZ, 77385), Yukatan, c. $12 \mathrm{~km} \mathrm{~N}$ of Piste, on road to Dzitas (c. $20^{\circ} 47^{\prime} \mathrm{N}, 88^{\circ} 34^{\prime} \mathrm{W}$ ), tropical seasonal forest, 20.07.1983, W. Maddison; $10^{7}$ (MCZ, 77380), San Luis Potosi, c. 7 km SE of Tamazunchale on road to Huejutla (c. $21^{\circ} 14^{\prime} \mathrm{N}, 98^{\circ} 44^{\prime} \mathrm{W}$ ), citrus orchard, 11.06.1983, W. Maddison; $3 \mathrm{O}^{7} \sigma^{7}, 5$ 우 (MCZ, 77393), San Luis Potosi, Xilitla, Cueva del Salitre (c. $21^{\circ} 23^{\prime} \mathrm{N}, 98^{\circ} 59^{\prime} \mathrm{W}$ ), c. $2000 \mathrm{ft}$ a.s.1., 13.06.1983, W. Maddison; 2 우 (MCZ, 77517), San Luis Potosi, Valles E1 Bañito, 27.06.1940, H. Hoogstraal.

COMMENTS. It is a rather common Neotropical species known to date from Mexico to Guyana [Chick- ering, 1946; Galiano, 1962, 1980; Logunov \& Marusik, 2003; present data]. New record for Guyana.

\section{Lyssomanes lancetillae Galiano, 1980} Figs 63-64.

MATERIAL. NICARAGUA: 1 (BMNH, 1953.4.7.410), (no exact locality), on bamboo stalk, 11.12.1941, J.J. Sanderson.

COMMENTS. To date this species has been known from Honduras only [Galiano, 1980]. It is the first record of the species after its original description. New record for Nicaragua.

Lyssomanes leucomelas Mello-Leitão, 1917 Figs 54-58.

MATERIAL. BRAZIL: $2 O^{7} O^{7}$ (ONHM), 'Rio Grande R' [S Minas Gerais state (SE Brazil), Rio Grande River], O. PickardCambridge collection, bottle 1730; 1 (MCZ, 77481), Est. Sao Paulo, Jundiaí, 10.1976, A. Schneble. - MEXICO: $1 \sigma^{7}$ (MCZ, 77515), no exact locality and date, Peckhams collection.

COMMENTS. To date this species has been known from Brazil and Argentina [Galiano, 1980; Logunov, 2002]. New record for Mexico.

This species is very close (or even identical) to $L$. penicillatus Mello-Leitão, 1927. A poor separation of two species was provided by Galiano [1980: 23-24], who also admitted that the latter name may be a junior synonym of L. leucomelas. More comparative materials are required to sort out this problem.

\section{Lyssomanes longipes (Taczanowski, 1871)}

MATERIAL. GUYANA: 1 ( (ONHM), "small C tangle \& long leaves on wall, Amatuk, 6/8/593/A, B.G.”, G.P. Lampel [handwritten label is illegible; apparently from Georgetown, Guyana]; 1 , 1 juv. $\mathrm{O}^{7}$ (ONHM), "running under long leaves in dark wall, Amatuk, 30/7/597, B.G.", G.P. Lampel [handwritten label is illegible; apparently from Georgetown, Guyana]; $1+$ (ONHM), "small tangle \& long leaves on wall, Amatuk, 6/8/593/B, B.G.”, G.P. Lampel handwritten label is illegible; apparently from Georgetown, Guyana]; $1 \mathrm{O}^{\text {T }}$ (ONHM), "along leaf wet down...[handwritten illegible label], Amatuk, 4/8/59/9, B.G.", G.P. Lampel [handwritten label is illegible; apparently from Georgetown, Guyana]; $10^{7}$ (ONHM), "on leaf in wallaber (?) nr. Amatuk, 27/7/596, B.G.", G.P. Lampel [handwritten label is illegible; apparently from Georgetown, Guyana]; 1 + (ONHM), "long leaf, wet down wallaber (?), Amatuk, 4/8/ 5920, B.G.", G.P. Lampel [handwritten label is illegible; apparently from Georgetown, Guyana]. - BRAZIL: $60^{7} \sigma^{7}, 3$ OO (MCZ, 77403-77406, 77419-77422, 77425, 77427), Amazonas, c. $80 \mathrm{~km}$ $\mathrm{N}$ of Manaus, Colosso Reserve, border of forest and its interior, 2.03-20.09.1990, H.G. Fowler; 12 O' $\sigma^{\prime}, 8$ 우 (MCZ, 77407-77418, 77424, 77434, 77435, 77438), same locality, 10.03-20.12.1989, H.G. Fowler; 1 (MCZ, 77428), Amazonas, c. $80 \mathrm{~km} \mathrm{~N}$ of Manaus, Cabo Frio Reserve, date unknown, but between 1989 and 1992, H.G. Fowler; 19 (MCZ, 77437), same locality, 6.12.1990, H.G. Fowler; 107,3 ㅇ (MCZ, 77430, 77440-77443), Amazonas, c. 80 $\mathrm{km} \mathrm{N}$ of Manaus, Km. 41 Reserve, forest interior, 21.01.1991, H.G. Fowler; 1 (MCZ, 77439), Amazonas, c. $80 \mathrm{~km} \mathrm{~N}$ of Manaus, Reserva Gaviao, forest interior, 24.04.1991, H.G. Fowler; 1 q (MCZ, 77445), Amazonas, c. $80 \mathrm{~km} \mathrm{~N}$ of Manaus, Reserva C. de Powell, forest interior, 23.04.1991, H.G. Fowler; 1 ( (MCZ, 77444), Amazonas, c. $80 \mathrm{~km} \mathrm{~N}$ of Manaus, Reserva C. de Powell $\left(2^{\circ} 24^{\prime} \mathrm{S}\right.$, $59^{\circ} 52^{\prime} \mathrm{W}$ ), interior of 10 ha plot, 11.10.1989, H.G. Fowler.

COMMENTS. To date this species has been known from Brazil, Guyana and French Guiana [Galiano, 

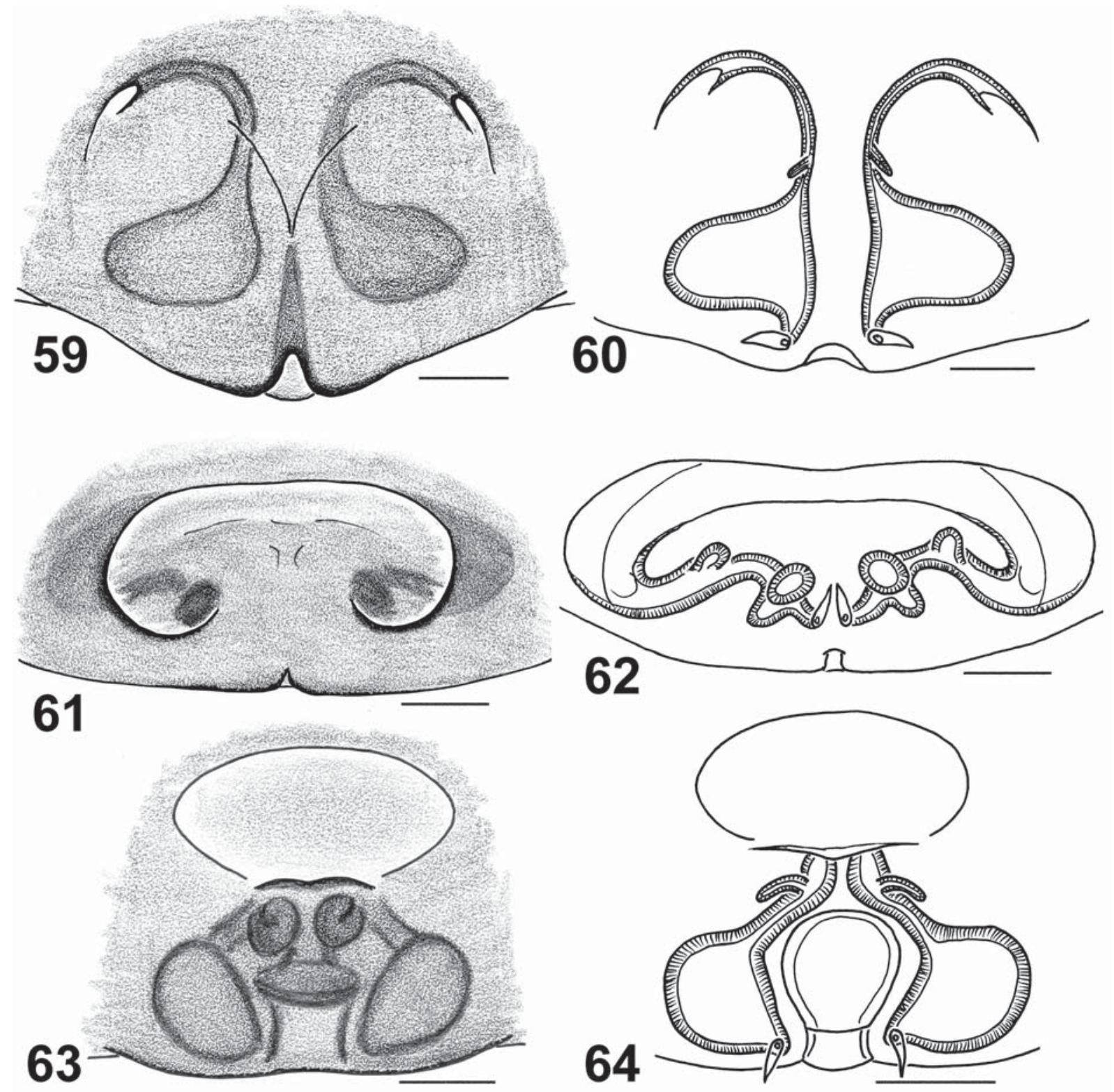

Figs 59-64. Copulatory organs of Lyssomanes malinche Galiano, 1980 (59-60, from Orizaba, Mexico), L tristis Peckham, Peckham et Wheeler, 1889 (61-62, from Rio de Janeiro, Brazil) and L. lancetillae Galiano, 1980 (63-64, from Nicaragua): 59, 61, 63 — epigyne, ventral view; $60,62,64$ - vulva, dorsal view. Scale bars: $0.1 \mathrm{~mm}$.

Рис. 59-64. Копулятивные органы Lyssomanes malinche Galiano, 1980 (59-60, из Орисаба, Мексика), L tristis Peckham, Peckham et Wheeler, 1889 (61-62, из Рио-де-Жанейро, Бразилия) и L. lancetillae Galiano, 1980 (63-64, из Никарагуа): 59, 61, 63 эпигина, вид снизу; 60, 62, 64 - вульва, вид сверху. Масштаб: 0,1 мм.

1980; Logunov, 2002; present data]. New record for Guyana.

\section{Lyssomanes limpidus Galiano, 1980}

MATERIAL. COLOMBIA: $1 \mathrm{O}^{7}$ (MCZ, 77535), Valle, Yotoko, gallery forest, 31.07.1977, W.G. Eberhard.

COMMENTS. To date this species has been known from Colombia only [Galiano, 1980, 1984; present data].
Lyssomanes malinche Galiano, 1980

Figs 59-60.

MATERIAL. MEXICO: 1 (MCZ, 77502), Orizaba, no date, N. Banks.

COMMENTS. To date this species has been known from two localities in Mexico (Jacala and Orizaba) only [Galiano, 1980; present data]. It is the first record of the species after its original description. 

1900

Lyssomanes mandibulatus F.O. Pickard-Cambridge,

MATERIAL. MEXICO: $1 \sigma^{7}$ (MCZ, 77507), Jalisco, Esta. Biol. Chamela, $100 \mathrm{~m}$ a.s.l., 09.1988, W.G. Eberhard.

COMMENTS. To date this central American species has been recorded from Mexico, Costa Rica and Panama [Galiano, 1980; Logunov \& Marusik, 2003; present data].

Lyssomanes miniaceus Peckham, Peckham et Wheeler, 1889

Figs 15-17.

MATERIAL. BRAZIL: $2 \sigma^{7} \sigma^{7}$ (ONHM), 'Rio Grande R' [S Minas Gerais state (SE Brazil), Rio Grande River], O. PickardCambridge collection, bottle 1730; $10^{7}$ (MNRJ 00971; det. by M.E. Galiano), Rio de Janeiro, Tijuca.

COMMENTS. To date this species has been known from Brazil and northern Argentina only [Galiano, 1962, 1980; present data].

The male identified here as L. miniaceus (Figs 1517 ) is identical with that identified by E. Galiano (her sample from the MNRJ was re-examined); both have the identical conformation of the male palps and the densely haired legs I and II (viz., dorsal and ventral rows of dense brownish hairs), including their femora (white hairs ventrally), with dark brown tarsi (Fig. 18).

One of the studied samples from the ONHM $\left(10^{7}\right.$; jar 2287, tube 22) contained label "Madagascar", which beyond doubt is a mistake because the genus Lyssomanes does not occur outside the Neotropical Region.

\section{Lyssomanes nigrofimbriatus Mello-Leitão, 1940}

MATERIAL. BRAZIL: $1 \sigma^{7}$ (MHNG), "Brazilien Nova Teutonia”, 300-500 m a.s.1., 07.1968, F. Plaumann; $1 \sigma^{7}$ (ONHM), 'Rio Grande R' [S Minas Gerais state (SE Brazil), Rio Grande River], O. Pickard-Cambridge collection, bottle 1730; 1 o (MCZ, 77481), Est. Sao Paulo, Jundiaí, 10.1976, A. Schneble.

COMMENTS. To date this species has been known from Brazil and Argentina only [Galiano, 1962, 1980; present data].

Lyssomanes nigropictus Peckham, Peckham et Wheeler, 1889

MATERIAL. SURINAME: $1 \sigma^{\top}$ (MCZ, 77482), Saramacca, Voltzberg-Raleighvallen Nature Reserve $\left(4^{\circ} 32^{\prime} \mathrm{N}, 56^{\circ} 32^{\prime} \mathrm{W}\right)$, 02.1982, D. Smith Trail.

COMMENTS. To date this species has been known from Ecuador, Brazil Guyana and Suriname [Crane, 1943; Galiano, 1962, 1980; Logunov, 2000b; present data]. New record for Suriname.

\section{Lyssomanes patens Peckham et Peckham, 1896}

MATERIAL. PANAMA: $2 \sigma^{\top} \sigma^{7}$ (MCZ, 77489, 77495), Panama Prov., Canal Zone, Barro Colorado Island, no date, A.M. Chickering. - COSTA RICA: $1 \sigma^{7}$ (MMUM, F3428.25), nr. Puerto Viejo, La Selva Biological Station, c. $50 \mathrm{~m}$ a.s.1., wet rainforest, canopy, 21-26.06.2013, D.V. Logunov.

COMMENTS. To date this species has been known from Honduras, Costa Rica and Panama [Chickering,
1946; Galiano, 1980; present data]. New record for Costa Rica.

\section{Lyssomanes remotus Peckham et Peckham, 1896}

MATERIAL. COLOMBIA: $10^{7}, 1$ (MCZ, 77480, 77511), Meta, c. $15 \mathrm{~km} \mathrm{SW}$ of Puerto Lopez, Had. Mozambique, $500 \mathrm{~m}$ a.s.1., 06.1975, W.G. Eberhard. - TRINIDAD \& TOBAGO: $20^{7} \sigma^{7}$, 2 우 (MCZ, 77484), Simla, 04.1964, A.M. Chickering.

COMMENTS. To date this species has been known from Panama, Colombia, Brazil and Trinidad \& Tobago [Galiano, 1980; Logunov, 2002; present data]. New records for Colombia and Trinidad \& Tobago.

\section{Lyssomanes santarem Galiano, 1984}

MATERIAL. BRAZIL: $1+$ (MCZ, 77472), Mato Grosso, c. $260 \mathrm{~km} \mathrm{~N}$ of Xavantina $\left(12^{\circ} 49^{\prime} \mathrm{S}, 51^{\circ} 46^{\prime} \mathrm{W}\right)$, gallery forest, 30.11.1968, expedition Xavantina-Cachimbo

COMMENTS. To date this species has been known from two localities in Brazil only [Galiano, 1984; present data]; it is the first record of the species after its original description.

Lyssomanes spiralis F. O. Pickard-Cambridge, 1900

MATERIAL. MEXICO: $1 \bigcirc^{7}$ (MCZ, 77497), Veracruz, Medias Aquas, no date, Nathan Banks Coll. - BELIZE: $10^{7}$ (MMUM), Las Cuevas research station, 24.06.2006, E. Shaw.

COMMENTS. It is a central American species recorded to date from Mexico, Guatemala, Belize and Nicaragua [Galiano, 1980; present data]. New records for Belize and Mexico.

\section{Lyssomanes tapirapensis Galiano, 1996}

MATERIAL. VENEZUELA: $1 \sigma^{7}$ (MCZ, 77534), Amazonas, Neblina Base Camp, Rio Mawarinuma $\left(0^{\circ} 50^{\prime} \mathrm{N}, 66^{\circ} 10^{\prime} \mathrm{W}\right), 140 \mathrm{~m}$ a.s.1., Terra firmo forest, 25.11-4.12.1984, A.L. Weitzman.

COMMENTS. To date this species has been known from Venezuela and Brazil [Galiano, 1996; present data]; it is the first record of the species after its original description. New record for Venezuela. 1889

Lyssomanes tenuis Peckham, Peckham et Wheeler,

MATERIAL. COLOMBIA: $1 \mathrm{O}^{7}, 1$ ( 1 (MCZ, 77510, 77533), Meta, c. $15 \mathrm{~km} \mathrm{SW}$ of Puerto Lopez, Had. Mozambique, $500 \mathrm{~m}$ a.s.1., 06.1975, W.G. Eberhard.

COMMENTS. It is a rather common Lyssomanes species recorded to date from Colombia, Ecuador, Brazil and Guyana [Galiano, 1962, 1980; Logunov, 2000a,b; Logunov \& Marusik, 2003; present data]. New record for Colombia. 1889

Lyssomanes tristis Peckham, Peckham et Wheeler,

Figs 21, 61-62.

MATERIAL. BRAZIL: 1 \& syntype (MNBG, Nr. 417), "Brasil, leg. V. Olf."; 1 9 (MCZ, 77513), Guanabara, Rio de Janeiro, 12.1970-01.1971, D. McGrath \& S.W. Camazine; 1 q (ONHM), 
'Rio Grande R' [S Minas Gerais state (SE Brazil), Rio Grande River], O. Pickard-Cambridge collection, bottle 1730 .

COMMENTS. To date this species has been known from Brazil and Argentina only [Galiano, 1962: sub $L$. dubius, 1980; present data]. The females of L. tristis have the rather characteristic yellow-orange carapace, with the markedly risen and contrastingly coloured (white) eye field.

\section{Lyssomanes unicolor (Taczanowski, 1871)}

MATERIAL. GUYANA: 1 (MCZ, 77505), British Guiana, Bartica Distr., Kartabo, 30.11.1920, W.M. Wheeler. - SURINAME: 1 ( $(\mathrm{MCZ}, 77483)$, Saramacca, Voltzberg-Raleighvallen Nature Reserve $\left(4^{\circ} 32^{\prime} \mathrm{N}, 56^{\circ} 32^{\prime} \mathrm{W}\right), 02.1982$, D. Smith Trail. TRINIDAD \& TOBAGO: 1 ( (MCZ, 77485), Blanchesseuse Beach area, 12.04.1964, A.M. Chickering. - PANAMA: 1 ㅇ (MCZ, 77495), Panama Prov., Canal Zone, Barro Colorado Island, no date, A.M. Chickering.

COMMENTS. It is a rather common Lyssomanes species recorded to date from Mexico in the north to Peru and south-eastern Brazil in the south [Crane, 1943: sub. L. beebei; Chickering, 1946: L. banksi and L. shropshirei; Galiano, 1962, 1980; Logunov, 2000a, 2002; Logunov \& Marusik, 2003; present data]. New records for Suriname and Trinidad \& Tobago.

\section{Discussion}

Despite a comparatively large number of Lyssomanes species described to date ( 88 in total; [Platnick, 2014; present data]), our knowledge both on taxonomic structure of the genus and on distribution of its species still remain rather fragmentary. Except for a few common and widespread species, such as L. amazonicus, L. jemineus, L. longipes or L. unicolor, almost a half $(44 \%)$ of the described species remains known from a single sex and/or from the type locality only. Of the 88 valid species of Lyssomanes, 49 are known from both sexes $(56 \%), 24$ are known from females $(27 \%)$ and 15 are known from males (17\%). Some species [e.g., L. convexus, L. dissimilis Banks, 1929, L. penicillatus Mello-Leitão, 1927, L. robustus (Taczanows$\mathrm{ki}, 1878$ ) and others] have been known from the late 19 th or early 20 th century and recorded several/many times from various places but yet from one sex only. This is because, as M.E. Galiano [1984] correctly stressed upon, matching sexes of the same Lyssomanes species is often very difficult. If the males have rather complex copulatory organs, some recognizable somatic characters (e.g. the structure of legs I; Figs 10, 18, 25 , etc.) or body coloration (e.g., Figs 4, 12, 26), the females of Lyssomanes have very simple copulatory organs and are often uniformly coloured (pale yellow in alcohol) having no colour pattern comparable to that of the corresponding males. Thus, unless both sexes were collected and preserved together, there is little/no chance to match them on the basis of museum samples containing singular specimens, which are evidently most common in natural history collections (e.g., see above under 'Material'). This problem requires special attention in the future and can apparently be resolved through collecting larger samples by modern effective methods such as fogging.

ACKNOWLEDGEMENTS. I wish to express my warmest thanks to the following curators: J. Beccaloni (BMNH), J. Dunlop (MNBG), A. Kury (MNRJ), L. Leibensperger (MCZ), J. Miller (NNMN), Z. Simmons (ONHM), and P. Schwendinger (MHNG), for giving access to the spider collections of their museums. I also wish to thank the Ministerio de Ambiente, Energia y Telecomunicaciones (San Jose, Costa Rica) and personally Mr. J.G. Sequeira for granting me permission to collect and study the Salticidae in Costa Rica in 2013 (export permission No. 042-2013-SINAC). My special thanks go to Yu.M. Marusik (Magadan, Russia) for his useful critical comments on the first draft helping to improve it.

\section{References}

Brignoli P.M. 1984. On some West Indian Mimetus and Lyssomanes (Araneae: Mimetidae, Salticidae) // Bull. Br. arachnol. Soc. Vol.6. Pt.5. P.200-204.

Chickering A.M. 1946. The Salticidae of Panama // Bull. Mus. comp. Zool. Harv. Vol.97. P.1-474.

Crane J. 1943. Spiders of the families Lyssomanidae and Salticidae from British Guiana and Venezuela // Zoologica (New York). Vol.28. P.125-138.

Dunlop J.A., Penney D., Jekel D. 2014. A summary list of fossil spiders and their relatives // Platnick N.I. (ed.) The world spider catalog, version 14.5 American Museum of Natural History, online at: http://research.amnh.org/entomology/spiders/ catalog/index.html (last updated 18.12.2013).

Galiano M.E. 1962. Redescripción de especies del género Lyssomanes Hentz, 1845 basadas en los ejemplares típicos // Acta Zool. Lillona. Vol.18. P.45-97.

Galiano M.E. 1980. Revisión del género Lyssomanes Hentz, 1845 (Araneae, Salticidae) // Op. Lilloana. Vol.30. P.1-104.

Galiano M.E. 1984. New species of Lyssomanes Hentz, 1845 (Araneae, Salticidae) // Bull. Br. arachnol. Soc. Vol.6. No.6. P.268276.

Galiano M.E. 1996. Descripción de tres nuevas especies de Lyssomanes de Brasil (Araneae, Salticidae) // Inheringia, Sér. Zool., Porto Alegre. Vol.81. P.23-30.

Jiménes M.L., Tejas A. 1993. Two new species of the genus Lyssomanes Hentz from the Cape Region, D.C.S., Mexico // J. Arachnol. Vol.21. P.205-208.

Logunov D.V. 2000a. Three new species of Lyssomanes Hentz, 1845 from Peru (Arachnida: Araneae: Salticidae) // Reichenbachia. Vol.33. P.267-270.

Logunov D.V. 2000b. A new species of Lyssomanes Hentz, 1845 from Brazil (Araneae: Salticidae) // Bull. Br. arachnol. Soc. Vol.11. Pt.8. P.343-344.

Logunov D.V. 2002. New species and new records of Lyssomanes Hentz, 1845 from Brazil (Arachnida: Araneae: Salticidae) // Reichenbachia. Vol.34. P.229-239.

Logunov D.V., Deza M. 2010. A description of the male of Lyssomanes euriensis Logunov, 2000 // Acta Arachnologica. Vol.59. No.1. P.21-23.

Logunov D.V., Marusik Yu.M. 2003. Taxonomic and faunistic notes on Chinoscopus Simon, 1900 and Lyssomanes Hentz, 1845 from the Neotropical Region (Araneae: Salticidae) // Bull. Br. arachnol. Soc. Vol.12. Pt.9. P.415-424.

Ono H. 1988. A revisional study of the spider family Thomisidae (Arachnida, Araneae) of Japan. Tokyo: National Science Museum. 252 p. 
Peckham G.W., Peckham E.G. 1896. Spiders of the family Attidae from Central America and Mexico // Occ. Pap. nat. Hist. Soc. Wiscons. Vol.3 P.1-101.

Platnick N. 2014. The World Spider Catalog, Version 14.5, (accessioned on January 21st 2014), American Museum of Natura History. Online at: http://research.amnh.org/entomology/spiders/catalog/INTRO1.html (Salticidae page last updated 13.12.2013)
Wunderlich J. 1986. Spinnefauna gestern und heute. Fossile Spinnen in Bernstein und ihre heute lebenden Verwandten. Wiesbaden: Bauer bei Quelle u. Meyer. 283 S.

Wunderlich J. 1988. Die Fossilen Spinnen (Araneae) im Dominikanischen Bernstein // Beitr. Araneologie. Bd.2. S.1-378.

Responsible editor K.G. Mikhailov 